\title{
TÜRK CEZA HUKUKUNDA CANAVARCA HİS
}

\author{
DOI: https://doi.org/10.33717/deuhfd.899904
}

\author{
Arş. Gör. Dr. Eylem BAŞ*
}

\section{Öz}

5237 sayılı Türk Ceza Kanunu'nun (TCK) 82. maddesinin (b) bendinde kasten öldürme suçunun "canavarca hisle” işlenmesi şeklindeki nitelikli hale yer verilmiştir. Ancak "canavarca hisle” öldürmeden anlaşılması gerekene ilişkin ne uygulamada ne de öğretide birlik bulunmaktadır. Söz konusu durum, Yargıtay'ın kararlarına bakıldı̆̆ında birbiriyle çelişen kararların verilmesine neden olmaktadır. Bu sorunlu duruma karşın, 7242 sayıl "Ceza ve Güvenlik Tedbirlerinin Infazı Hakkında Kanun ile Bazı Kanunlarda Değişiklik Yapılmasına Dair Kanun"un 31100 sayılı Resmî Gazete'de yayınlanarak 15.4.2020 tarihinde yürürlüğe girmesiyle birlikte TCK'nın 86. maddesinin 3. fikrasina (f) bendi eklenerek kasten yaralama suçunun "canavarca hisle” işlenmesi, kasten yaralama suçunun nitelikli olarak öngörülmüştür. Bu kapsamda çalışmada “canavarca his” kavramından neyin anlaşılması gerektiği hususu incelenmektedir. Ardındansa söz konusu kavram yerine TCK'da gerçekleştirilecek değişiklikle başka bir kavramın kullanılması ya da bu kavramın kullanılması konusunda ısrarcı olunacaksa, TCK'nın 6. maddesinde bu kavramın tanımının yapılmasının gerekliliği üzerinde durulmaktadır.

\section{Anahtar Kelimeler}

Türk Ceza Hukuku, Canavarca His, Eziyet, Kasten Öldürme, Kasten Yaralama

\section{MONSTROUS FEELING IN TURKISH CRIMINAL LAW}

\section{Abstract}

In the subparagraph (b) of Article 82 of the Turkish Penal Code numbered 5237 (TCK), the qualified form of committing the crime of intentional killing

Ankara Üniversitesi Hukuk Fakültesi, Ceza ve Ceza Muhakemesi Hukuku Anabilim Dalı (e-posta: ebas@ankara.edu.tr) ORCID: https://orcid.org/0000-0002-3400-2042 (Makalenin Geliş Tarihi: 20.12.2020) (Makale Gönderilme Tarihi: 23.12.2020/Makale Kabul Tarihi: 26.01.2021) 
with a "monstrous feeling" is included. However, there isn't any unity neither in practice nor in doctrine regarding what should be understood without intentional killing with a "monstrous feeling". This situation causes contradictory decisions to be made by the Supreme Court when looking at the decisions of the Supreme Court. Despite this problematic situation, with the publication of the "Law on the Execution of Penalties and Security Measures and the Law on the Amendment of Some Laws" numbered 7242 in the Official Gazette numbered 31100 and coming into force on 15.4.2020, subparagraph (f) was added to the third paragraph of Article 86 of the TCK. With this subparagraph (f) committing the crime of intentional injury with a "monstrous feeling" is stipulated as a crime of qualified intentional injury. In this context, the concept of "monstrous feeling" is examined in this study. Afterwards, it is recommended to use another statement with the change to be made in the TCK instead of the statement of "monstrous feeling". However, although it will be insistent on using this statement of "monstrous feeling", the necessity of defining this statement in Article 6 of the TCK is emphasized.

\section{Keywords}

Turkish Criminal Law, Monstrous Feeling, Tortment, Intentional Killing, Intentional Injury 


\section{GİRIŞ}

TCK'nın 82. maddesinin (b) bendinde kasten öldürme suçuyla ilgili olarak ilki "canavarca hisle"; ikincisiyse "eziyet çektirerek" olmak üzere iki nitelikli hale yer verilmiştir. Nitekim TCK'nın 81. maddesinde kasten öldürme suçunun yaptırımı "müebbet hapis cezası" olarak düzenlenmişken, TCK'nın 82. maddesinde nitelikli hallerin varlığı halinde yaptırım olarak "ağırlaştırılmış müebbet hapis cezası" öngörülmektedir. Ayrıca 7242 sayılı "Ceza ve Güvenlik Tedbirlerinin İnfazı Hakkında Kanun ile Bazı Kanunlarda Değişiklik Yapılmasına Dair Kanun"un 31100 sayılı Resmî Gazete'de yayınlanarak 15.4.2020 tarihinde yürürlüğe girmesiyle birlikte TCK'nın 86 . maddesinin 3. fikrasına (f) bendi eklenerek kasten yaralama suçunun "canavarca hisle" işlenmesi, kasten yaralama suçunun nitelikli olarak öngörülmüştür. 765 sayılı Türk Ceza Kanunu (ETCK) dönemindeyse "canavarca bir his sevki ile" ifadesine yalnızca kasten öldürme suçuyla ilgili olarak 450. maddesinin (3). bendinde yer verilmişti.

Bu kapsamda, çalışmada "canavarca his" kavramı incelenecek ve bu kavramdan neyin anlaşılması gerektiğine ilişkin değerlendirmelerde bulunulacaktır. Söz konusu değerlendirmelerde bulunabilmek için öğretide ve uygulamada bu kavramın ne şekilde anlaşıldığına değinilecektir. Bunun için kasten öldürme suçunun "canavarca hisle" mi yoksa "eziyet çektirerek" mi işlendiği sorununun tespiti de ele alınacaktır. Ayrıca kasten yaralama suçunun "canavarca hisle" işlenmesinden bahsedilecektir. Ardındansa "canavarca his" kavramı yerine başka bir kavramın kullanılmasının mümkün olup olmadığı hususu üzerinde durulacaktır.

\section{I. "CANAVARCA HIS" KAVRAMI}

\section{A. Tanım Denemesi}

TCK'da “canavarca his” kavramının tanımlanmadığı görülmektedir. Benzer durum ETCK bakımından da geçerlidir. Bu kapsamda kavramın tanımının yapılması öğretiye ve uygulamaya bırakılmıştır ${ }^{1}$, Tanımın yapılmamasının yerinde olduğu, böylece somut olaya göre değerlendirmenin gerçekleştirilmesinin uygulama bakımından mümkün kılındığı, her kavramın tanımının yapılması halinde kanunun tanımla dolacağ

Centel, Nur/Zafer, Hamide/Çakmut, Özlem: Kişilere Karşı İşlenen Suçlar, C. I, 3. Bası, Beta Basım Yayım Dağıtım A.Ş., İstanbul 2016, s. 47.

2 ETCK'nın 450. maddesinin 3. fikrasında “"“canavarca bir his şevki ile” öldürmeden söz edilip bu deyimin tanımı yapılmadığına göre, öldürmenin canavarca hisle işlenip işlen- 
"canavarca his" kavramı muğlaktır. Elbette ki bu kavramdan bahsedildiğinde ister istemez her bir bireyin aklında belli bir çağrışım oluşmaktaysa da oluşan bu çağrışımın herkes bakımından ortak olduğunu söylemek iddialı olur.

Özü itibariyle bir kimsenin öldürülmesinin dahi canavarlık olarak kabul edilmesi mümkündür ${ }^{3}$. Canavarca histen anlaşılması gerekenin belli olmaması, bu belirlemenin yapılmasının güç olması ${ }^{4}$, sorunlara yol açmakta ve uygulamada farklı farklı kararların verilmesine neden olmaktadır. Nitekim Yargıtay'ın dahi birbiriyle çelişen kararları söz konusudur.

Yargıtay'ın kararlarına bakıldı ğında "canavarca his" kavramının tanımının yapılmadığ 1 , örneklemek suretiyle söz konusu değerlendirmeyi yaptığ 1 görülmektedir. ${ }^{6}$ Ancak söz konusu durum eleştirilmelidir. Zira bu kavramdan neyin anlaşılması gerektiği net değildir ${ }^{7}$. Tanımın yapılmasının zor olmasının bunun olanaksız olduğu anlamına gelmeyeceği belirtilmekteyse $\mathrm{de}^{8}$ YCGK, 15.4.1963 tarihli kararında "ne gibi duygularin canavarca olduğunu tanımlamak imkânsızdır" demiştir'. Somut olaya ilişkin çözümün be-

mediğini yargıcın, olayın mahiyetini ve eylemin işleniş biçimini göz önünde bulundurarak takdir edeceği kuşkusuzdur. Sanıkların maktulleri hiç tanımadıkları halde sırf kendi görüşlerinde olmamalarından dolayı ve müştereken onları bayıltıncaya kadar dövmeleri ve daha sonra da bu kişileri bağlayarak çuvala koymaları, işlemiş oldukları bu suçun delil ve emarelerini ortadan kaldirmak, daha doğrusu kendilerini ele vermek korkusuna yönelik olup, bu hali kanunun amaçladiğı anlamda «canavarca his» biçiminde kabul etmek olanaksızdır." Askeri Y. 3. CD. 450/507 T. 29.12.1981 (Karar metni için bkz. Selçuk, Sami: "Karşılaştırmalı Hukuk Açısından Canavarca His Sevkiyle Adam Öldürme", Yargitay Dergisi, C.14, S. 4, Ekim 1988, s. 480)

3 Hafizoğulları, Zeki/Özen, Muharrem: Türk Ceza Hukuku Özel Hükümler Kişilere Karşı Suçlar, 6. Bası, US-A Yayıncılık, Ankara 2017, s. 48; Hafızoğulları, Zeki/ Ketizmen, Muammer: "5237 sayılı Türk Ceza Kanunu'nda Hayata Karşı Suçlar”, Y. 66, S. 1, 2008, s. 148.

4 Toroslu, Nevzat: Ceza Hukuku Özel Kısım, 10. Bası, Savaş Yayınevi, Ankara 2019, s. 30.

5 Otacı, Cengiz: Genel Hükümlerle Bağlantılı Olarak Kasten İnsan Öldürme Suçları, 1. Bası, Seçkin Yayıncılık, Ankara 2009, s. 488.

6 "Uygulamalarda Yargıtay'ın tanımlamadan ziyade örneklemelerle kavramları açıkladiğı, uygulayıcıya, olayına göre yorum yapma imkânı tanıdı ̆̆ görülmektedir" YCGK, 520/19, T. 1.2.1988 (Karar metni için bkz. Savaş/Mollamahmutoğlu, C. 3, s. 40864090)

7 Selçuk, "Canavarca", s. 480-481.

8 Selçuk, "Canavarca", s. 480-481.

9 YCGK 1-17/1, 15.4.1963 T. (Karar metni için bkz. Savaş, Vural/Mollamahmutoğlu, Sadık: Türk Ceza Kanununun Yorumu, C. 3, 1. Bası, Seçkin Yayınevi, Ankara 1995, s. 4100-4102) 
lirlenmesi, buna karşın teorik çerçevenin çizilmemesi ${ }^{10}$, çelişkili kararların verilmesine neden olmaktadır. Öğretide "canavarca his" üzerinde yeterli çalışmanın bulunmamasının da yargı kararlarının oluşumuna etki edememesine sebep olduğu yönünde eleştirildiği görülmektedir ${ }^{11}$.

"Canavarca his" ifadesinin anlaşılabilmesi için öncelikle "canavar" kavramına bakmakta fayda vardır. Bu kapsamda "canavar" kavramının anlamının tespiti bakımından etimolojiden yararlanmak gerekmektedir ${ }^{12}$. Türk Dil Kurumu'nun sözlüğünde "masallarda sözü geçen yabani, yırtıcı hayvan", "köpek balı̆̆l”, "haşarı, yaramaz çocuk", "kurt, domuz vb. cana klyan yaban hayvanı", "acımasız, kötü ruhlu, zalim (kimse)", "herhangi bir şeye çok düşü̈ olan" şeklinde tanımlanmaktadır ${ }^{13}$. Farsçada bileşik sıfat olan "canavar" ("can-aver", "can-ver") "canl, yaşayan"; isim olaraksa "zararlı hayvan, domuz" anlamına gelmektedir" ${ }^{14}$. Hukuk sözlüğündeyse "vahşi hayvan, ejderha" olarak tanımlandığ 1 görülmektedir ${ }^{15}$. "Canavarca" ifadesi sıfat olarak kullanıldığında "canavar gibi"; zarf olarak kullanıldığındaysa "canavara uygun bir biçimde, canavarcasina" anlamına gelmektedir" ${ }^{16}$. Bu kapsamda "canavarca his"sin Türkçede "yabancll ve acımasızca his" şeklinde kullanıldığı belirtilmektedir ${ }^{17}$.

“Canavar" kavramının TCK'nın 82. maddesinin (b) bendinde esas olarak yırtıcı hayvan anlamında kullanıldığı, bu hayvanın özelliğinden yola çıkmak suretiyle bir kimseyi öldüren failin kötülügüne işaret edildiği söylenmektedir" ${ }^{18}$. Bu kapsamda "acımasızca, zalimce, vahşice, vahşi hayvan gibi; bu tür bir hisle” bir kimsenin öldürülmesi şeklinde tanımlanmaktadır ${ }^{19}$.

YCGK ise 2002/425 sayılı kararında, "canavar" kavramının cana kıyan yaban hayvanı anlamına gelmesinden hareketle kasten öldürme suçunun "canavarca hisle" işlenmesi bakımından kanun koyucunun mecaz yaptığına

\footnotetext{
10 Otacı, Öldürme, s. 489.

11 Otacı, Öldürme, s. 487.

12 Selçuk, "Canavarca", s. 3013.

13 Türk Dil Kurumu, Türkçe Sözlük, 11. Bası, Türk Dil Kurumu Yayınları, Ankara 2011, s. 440.

14 Devellioğlu, Ferit: Osmanlıca - Türkçe Ansiklopedik Lugat, 31. Bası, Aydın Kitabevi, Ankara 2015, s. 140.

15 Yılmaz, Ejder: Hukuk Sözlüğü, 9. Bası, Yetkin Yayınları, Ankara 2005, s. 188.

16 Türk Dil Kurumu, s. 440.

17 Selçuk, "Canavarca", s. 468.

18 Özen, Mustafa: Ceza Hukuku Özel Hükümler, 3. Bas1, Adalet Yayınevi, Ankara 2019, s. 137.

19 Yilmaz, s. 188.
} 
işaret etmiştir ${ }^{20}$. Ardındansa "satanist inançlar doğrultusunda toplum bilinci ve ahlakının geniş tepkisini çeken, amacı itibariyle tehlikeli ve vahşi kötülük eğilimini sergileyen psikolojik bir güdü altında" bir kimsenin öldürülmesini bu kapsamda kabul etmiştir. Nitekim aynı olayla ilgili olarak Y. 1. CD., 2002/361 sayılı kararında insanın kurban edilmesinin inanç ya da düşünce yahut da somut olaydaki gibi şeytani bir gayeyle işlenmesi olarak kabulünün toplum bakımından tehlikeli ve vahşilik olduğunu belirtmiştir. Nitekim günümüzde artık insan hayatının her şeyin üzerinde tutulması gerekliliği evrensel bir anlayıştır ${ }^{21}$. İlk derece mahkemesi ise 5.6.2002 tarihli 107-114 sayılı kararında bizatihi satanist düşünceye sahip olunarak, bu düşünce etrafında bir kimsenin öldürülmesinin "canavarca his" olarak kabul edilemeyeceğini belirtmiştir ${ }^{22}$. İlk derece mahkemesinin, Y. 1. CD.'nin ve YCGK'nın görüşlerine bakıldığında dahi "canavarca his" ifadesinin aynı şekilde yorumlanmadığı görülmektedir. Esasında sorunun temelinde "canavar" kavramından neyin anlaşılması gerektiğine ilişkin tereddüt yatmaktadır. Nitekim bu kavramdan "yırtıcı bir hayvan" anlaşılıyor ve bu kapsamda mecaz yapilıyor olsa dahi söz konusu durum bir sonraki başlıkta üzerinde durulacak olan eziyet çektirerek öldürmeyi de akla getirmektedir. Yine bu ifadeden mecaz olarak "yırtıcı bir hayvan"ın anlaşılması da bizatihi sorunludur. Nitekim söz konusu durumda yırtıcı hayvan, hayatta kalabilmek ve karnını doyurabilmek adına başka bir canlıyı öldürmektedir.

Her ne kadar Türkçeye "canavar" olarak çevrilse de söz konusu nitelikli halin kaynağını oluşturan 1889 tarihli İtalyan Ceza Kanunu'nun (İt. CK) 366. maddesinin 3. bendinde bunu ifade etmek için "brutale" kelimesinin kullanıldığı ve bu ifadeninse kökenine inildiğinde "brutus" kelimesiyle karş1laşllacağı, bununsa "brutus biçiminde öldürme" olup, "salt kalleşlik (yabanıl, acımasız, vicdansız, zorba kötülük) dürtüsüyle insan öldürme" anlamına geldiği belirtilmektedirr ${ }^{23}$. Yine bu kapsamda "insafslz bir zihniyetin hakimiyeti altında öldürme" olarak da tanımlanmaktadır. Mehaz kanundan

Ancak YCGK'nın 1.2.1988 tarihli kararında, "canavar" kavramını mecazi anlamından ziyade gerçek anlamını temel alarak yorumladığı yönünde bkz. Selçuk, "Canavarca", s. 467.

21 Y. 1. CD. E. 2001/4274 K. 2002/361 T. 6.2.2002 (Karar metni için bkz. www.kazanci.com) (Erişim Tarihi: 1.12.2020)

22 YCGK E. 2002/1-294 K. 2002/425 T. 17.12.2002 (Karar metni için bkz. www.kazanci.com) (Erişim Tarihi: 5.12.2020)

23 Selçuk, Sami: “Ana Dili Bilinci, Türkçe ve Hukuk Dilimiz”, Dokuz Eylül Üniversitesi Hukuk Fakültesi Dergisi, Prof. Dr. Durmuş Tezcan'a Armağan, C. 21, Özel Sayı, 2019, s. 3013 . 
"canavarca" ş̧eklinde ifade edilmek suretiyle alınan ifadenin "kötülük, kötü yüreklilik, yabanıl, vahşi, hayvanımsı, kaba, hoyrat, sert, acımasız" anlamına geldiği ve sonuç olarak "yalnızca yabanıl (hayvanca) kötü yüreklilik itkisi (içtepisi) ile” şeklinde anlaşılması gerektiği belirtilmektedir. Bu kapsamda "canavarca his" ifadesinin masallarda yer alan kurt, domuz gibi cana kıyan, yabanıl, yırtıcı hayvanla herhangi bir ilgisi bulunmamaktadır. $\mathrm{Bu}$ nedenle mehaz kanundan birebir çeviri yapmak yerine; "canavarca" ifadesinin kullanılması yerinde olarak eleştirilmektedir. Ayrıca mehaz kanunda yer alan "yalnızca" ifadesinin de "canavarca" ifadesinden evvel kullanılmaması bir diğer sorunu oluşturmaktadır. Örneğin (A)'nın babası (B)'yi öldüren (C)'den öç almak amacıyla (C)'yi öldürmesi halinde (A)'da canavarca his olsa dahi (A) yalnızca canavarca hisle hareket etmediğinden hakkında söz konusu nitelikli hal uygulanmamalıdır ${ }^{24}$. Yine birkaç kuruş için bir kimsenin öldürülmesi halinde de bu nitelikli halin uygulanmasından bahsedile$\mathrm{mez}^{25}$. Ancak TCK'da "yalnızca" ifadesine yer verilmediğinden başkaca sebeplerin varlığı halinde dahi olayın özelliklerine göre canavarca hissin varlığından bahsetmenin mümkün olduğu ileri sürülmektedir ${ }^{26}$.

Alman Ceza Kanunu'nun (Al. CK) kasten öldürme suçunun nitelikli hallerini ifade etmek üzere kullanılan ve "cinayet" başlı̆̆ını taşıyan 211. paragrafının 1. fikrasında katilin müebbet hapis cezasıyla cezalandırılacağ 1 , 2. fikrasındaysa katilin "öldürme zevki, cinsel güdülerini tatmin, açgözlülüğü ya da bu gibi alçakça güdüleri nedeniyle; kötü niyetle, acımasız bir şekilde veya toplum için genel tehlike yaratan araçlarla; bir suçu mümkün kılmak ya da gizlemek için bir insanı öldüren kişi” olduğundan bahsedilmiştir. Burada öldürme zevki, cinsel güdülerin tatmini ya da açgözlülük alçakça güdülerin yasal örneklerini oluşturmaktadır ${ }^{27}$. Söz konusu hükümdeki "öldürme zevki" TCK'nın 82. maddesinin (b) bendindeki "canavarca his"se; "acımasız bir şekilde öldürme" ise "eziyet çektirerek" öldürmeye

24 Ancak ETCK'nın 450. maddesinin (10). bendinde kasten öldürme suçunun "kan gütme saikiyle" işlenmiş olmasından bahsedilmesine karşın bu ağırlaştırıcı nedenin uygulama alanı bulabilmesi için "yalnızca kan gütme saikiyle" işlenmesinin arandığı yönünde bkz. Selçuk, "Canavarca", s. 467-469, 478.

25 Erem, Faruk: "Adam Öldürme”, Ankara Üniversitesi Hukuk Fakültesi Dergisi, C. 10, S. 1, 1953, s. 55.

26 Önder, Ayhan: Şahıslara ve Mala Karşı Cürümler ve Bilişim Alanında Suçlar, Filiz Kitabevi, İstanbul 1994, s. 27; YCGK 1-17/1, 15.4.1963 T. (Karar metni için bkz. Savaş/Mollamahmutoğlu, s. 4100-4102)

27 Kühl, Kristian: Lackner/Kühl Strafgesetzbuch Kommentar, 29. Aufl., Verlag C.H. Beck oHG, München 2018, StGB § 211, Rn. 4. 
tekabül etmektedir. Bu kapsamda Al. CK'da, TCK'da olduğu gibi "canavarca his" kavramından bahsedilmemektedir. Nitekim "öldürme zevki", Alman Federal Yargıtayı'nca bir insanın hayatına son vermeye ilişkin "doğal olmayan bir sevinç" şeklinde tanımlanmaktadır ${ }^{28}$. Ancak bu tanım, ister istemez failin akli dengesi bakımından sorunların varlığını akıllara getirmektedir ve bu nedenle eleştirilmektedir ${ }^{29}$. Zira bir kimseyi öldürmenin "doğal" sevinci diye bir şey yoktur ${ }^{30}$. Bu kapsamda failde başkalarının yaşamını aşağ 1 görme ve hiçe sayma şeklindeki duygunun varlığı aranmaktadır. Ayrıca failin bu fiili gerçekleştirmesi bakımından mağdurun faile herhangi bir neden vermemiş olması gerekmektedir. Tesadüf eseri failin önüne çıkan bir kimseyi öldürmeye ilişkin saf kötülüğü, tümüyle keyfiyet gereği ya da öldürmeden haz alması, adeta amiyane tabiriyle "spor olarak mağdur avina çıkması" bu kapsamda değerlendirilmelidir. Mağdurun ölümü, failin tek amacıdır. "Acımasız bir şekilde" öldürme kapsamında ise tıpkı "eziyet çektirerek" öldürmede olduğu gibi, öldürmek için gerekenin ötesinde mağdura acı veya 1 zdırabın çektirilmesi kabul edilmektedir ${ }^{31}$. Sırf insan yaşamının sonlandırılmasına ilişkin zevk ve bu zevki tatmin etmek amacıyla işlenen kasten öldürme suçu bakımından canavarca hissin varlığının kabul edilmesi gereklidir $^{32}$. Bu kapsamda TCK'nın 82. maddesinin (b) bendinden öngörülen "canavarca his" kavramı yerine bu kavramı ifade etmek üzere Al. CK' da yer alan "öldürme zevki" kavramının kullanılması önerilebilir.

TCK'nın 82. maddesinin (b) bendinde saikten değil, "his"ten bahsedilmiştir. Ancak failin iç dünyasıyla ilgili olan söz konusu hissin, saik kapsamında düşünülmesi gereklidirr ${ }^{33}$. Nitekim saik, faili davranışta bulunmaya

BGH Urt. v. 7.7.1953 - 1 StR 195/53, BeckRS 1953, 31370823 (Karar metni için bkz. https://beck-online.beck.de/Dokument?vpath=bibdata\%2Fents\%2Fbeckrs\%2F1953\%2 Fcont\%2Fbeckrs.1953.31370823.htm\&anchor=Y-200-GE-BGH-D-1953-07-07-AZ1STR19553) (Erişim Tarihi: 6.12.2020)

Schneider, Hartmut: Münchener Kommentar zum StGB, Bd. 4, 3. Aufl., Verlag C. H. Beck, München 2017, StGB § 211, Rn. 49.

30 Neumann, Ulfrid/Saliger, Frank: Nomoskommentar Kindhäuser/Neumann/Paeffgen, Strafgesetzbuch, 5. Aufl., Nomos, StGB § 211, Rn. 8.

31 Eser, Albin/Stenberg-Lieben, Detlev: Schönke/Schröder Strafgesetzbuch Kommentar, 30. Aufl., Verlag C.H. Beck oHG, München 2019, "StGB § 211 Mord”, Rn. 15, 27.

32 Önder, s. 27; Özbek, Veli Özer/Doğan, Koray/Bacaksız, Pınar: Türk Ceza Hukuku Özel Hükümler, 15. Bası, Seçkin Yayıncılık, Ankara 2020, s. 125; Artuk, Mehmet Emin/Gökcen, Ahmet/Yenidünya, A. Caner: Türk Ceza Kanunu Şerhi, C. 2, 2. Bası, Adalet Yayınevi, Ankara 2014, s. 3009-3010; Centel/Zafer/Çakmut, s. 47.

33 Otacı, s. 489-490; Otacı, Cengiz: "Karar İncelemesi Kan Gütme Saikiyle ve Canavarca Hisle Kasten Öldürme Suçu", İstanbul Üniversitesi Hukuk Fakültesi Mecmuası, C. LXXI, S. 1, 2013, s. 1494. 
iten neden, itici güç olarak tanımlanmaktadır. Bu kapsamda amaçtan ayrılır. Bazı hallerde failin amacının aynı zamanda saikini oluşturması mümkünse de çoğu zaman bu iki husus birbiriyle örtüşmez. Örneğin A, intikam almak için B'yi öldürdüğünde, “intikam” saiki, "B'nin ölümü” ise amacı oluşturmaktadır ${ }^{34}$. Fail tarafından gerçekleştirilen davranışın sosyal değerinin ve bu kapsamda "iyi" ya da "kötü" olarak değerlendirilebilmesi için faili davranışı gerçekleştirmeye iten saik, önem taşımaktadır. Saik, davranışın kast veya taksirden evvel gelen psişik nedeni olup, dürtü, içgüdü ve duygulardan ibarettir. Örneğin fakirlere yardım etme saikiyle hırsılık yapanla, yaz tatiline gidebilmek için hırsızlık yapan her ne kadar hırsılılı suçunun faili olsalar da moral açıdan söz konusu iki saik birbirinden farklıdır ${ }^{35}$. Benzer durum, kasten öldürme suçu için de geçerlidir. Ancak burada hırsızlık suçundan farklı olarak "canavarca his", TCK'nın 61. maddesi uyarınca temel cezanın belirlenmesinde değil, kanun koyucu tarafindan özel olarak TCK'nın 82. maddesinin (b) bendinde öngörüldüğünden, suça etki eden yani suçun tali kurucu unsuru olarak ortaya çıkmaktadır.

\section{B. Öğretinin ve Uygulamanın Kasten Öldürme Suçu Özelinde "Canavarca His" Kavramına İlişskin Yaklaşımı ve Bu Yaklaşımın Eleştirisi}

Öğretide, canavarca hissin, toplum bilincinin ve ahlakının tepkisine neden olan, failin amaçladığı nedenle, gerçekleştirdiği netice bakımından nicel açıdan orantısızlığın bulunduğu, her türlü emare ve delille kanıtlanabilen ve de özünde hoyrat ve yabanıl kötülük eğilimi bulunan psikolojik içtepi şeklinde tanımlandığ görülmektedir. Ayrıca "canavarca his" failin "ahlaki düşüklüğünün” de göstergesi olarak yorumlanmaktadır ${ }^{36}$. Nitekim söz konusu nitelikli halin kaynağını oluşturan 1889 tarihli İt. CK’nın 366. maddesinin 3. bendinin gerekçesinde "canavarca his”ten ölüm neticesiyle faili bu öldürme davranışına iten neden arasındaki ciddi derecede ölçüsüzlüğün ve orantısızlı̆̆ın anlaşılması ve bunun nesnel bir ölçüt olarak kabul edilmesinin gerektiği belirtilmiştir. Zira söz konusu durum fiilin değersizliğini ve gereksizliğini göstermektedir ${ }^{37}$. Ancak faili kasten öldürme suçunu işlemeye iten saikin, diğer insanlar tarafından "kötü" ya da "iğrenç" olarak

\footnotetext{
34 Öztürk, Bahri/Erdem, Mustafa Ruhan: Uygulamalı Ceza Hukuku ve Güvenlik Tedbirleri Hukuku, 20. Bas1, Seçkin Yayınc1lık, Ankara 2020, s. 247.

35 Toroslu, Haluk: "Temel Cezanın Belirlenmesinde Amaç ve Saik”, Uğur Alacakaptan’a Armağan, C. I, 1. Bası, İstanbul Bilgi Üniversitesi Yayınları, İstanbul 2008, s. 698-700.

36 Selçuk, "Canavarca", s. 469-470, 481-482.

37 Selçuk, "Canavarca", s. 468-469, 476-477.
} 
kabul edilmesi tek başına canavarca hissin varlığını göstermemektedir ${ }^{38}$. Örneğin eşinin kendisini aldattığ almak amaciyla öldürülmesini Yargıtay her ne kadar "canavarca his" kapsamında kabul etmişse ${ }^{39}$ de burada "canavarca his" yoktur.

Yargıtay bir diğer kararındaysa sanığın başkasıyla evli olmasına karşın başka bir kimseyle birlikte yaşaması ancak sanığın çalışmaması ve birlikte yaşadığı kişiye ve oğluna kötü davranıp dövmesi üzerine ayrılmaları ancak sanığın bunu kabullenemediği, sanığın karşı tarafı sürekli telefonla arayarak tehdit ettiği daha sonra ise karşı tarafın oğlunun anneannesinde kaldığını öğrendiği gün, karşı tarafı arayarak "sana acı duyuracă̆ım bak diyerek telefon açıkken av tüfeği ile uyumakta olan mağdura peş peşe birden fazla ateş ederek silah seslerini ve mağdurun çı̆̆llklarını" dinlettiği olayda canavarca hissin varlığını kabul etmiştir. Nitekim Yargıtay'a göre sanığın bu davranışının toplumun ortak bilincince hiçbir zaman onaylanması mümkün değildir ve sanık, vahşiliğini ve kötülüğünü göstermiştir ${ }^{40}$. Ancak bu kararda failin saikinden ziyade fiilin işleniş şeklinden hareketle canavarca hissin varllğından bahsedilmesi sorunludur ${ }^{41}$.

Bir diğer tanımlamaysa "canavarca his”ten öldürme amacından daha ileri giden vahşi davranışların anlaşılması gerektiği şeklindedir ${ }^{42}$. Ancak bu tanımda suçu işlemeye iten güdüyle suçun gerçekleştiriliş şekli birbirine karıştırılmaktadır.

Diğer bir tanımlamaysa faili suç işlemeye yönelten saikin, bir insanın duyabileceği hislerin hiçbiriyle açıklanamaması yani anlamsız olmasıdır ${ }^{43}$. Yani faili suç işlemeye yönelten saikin, normal şekilde bir insanın duyabi-

\footnotetext{
38 Selçuk, "Canavarca", s. 469.

39 "Üç yaşında olan maktulenin annesi Zeytin' in sanı̆̆ın gayriresmi kocası Gazi ile ilişkisi olmasına kızan sanığın kocası ile ilişsi kuran Zeytin'den sırf intikam almak için günahsız üç yaşında maktuleyi boğarak öldürmesinde canavarca bir his içinde olduğu açıkça ortada olduğu halde saniğın TCK.nun 450/3 yerine 448. madde ile cezalandirlmast suretiyle öldürme suçunun niteliğinde hataya düşülmesi," Y. 1. CD. E. 1984/2469 K. 1984/2730 T. 12.6.1984 (Karar metni için bkz. www.kazanci.com) (Erişim Tarihi: 1.12.2020) Y. 1. CD. E. 2004/2994 K. 2004/4402 T. 29.12.2004 (Karar metni için bkz. www.kazanci.com) (Erişim Tarihi: 2.12.2020)

41 Tezcan, Durmuş/Erdem, Mustafa Ruhan/Önok, Murat: Teorik ve Pratik Ceza Özel Hukuku, 17. Bası, Seçkin Yayıncılık, Ankara 2019, s. 155-156.

42 Dönmezer, Sulhi: Kişilere ve Mala Karşı Cürümler, 16. Bası, Beta Basım Yayım Dağıtım A.Ş., İstanbul 2001, s. 51.

43 Erman, Sahir/Özek, Çetin: Ceza Hukuku Özel Bölüm Kişilere Karşı İşlenen Suçlar, Dünya Yayıncılık A.Ş., İstanbul 1994, s. 39.
} 
leceği hislerin herhangi birisiyle izahının mümkün olmaması ve böylesine anlamsız bir nedenle bir insanın hayatına son veren failin "canavarca his"le davranışta bulunduğunun kabul edilmesidir. Bu kapsamda örnek olarak kişinin gördüğü rüyanın etkisinde kalarak çocuğunu öldürmesi halinde cennete gideceğine inandığ 1 için çocuğunu öldürmesi, yine yaşadığı yerde ortaya çıkan salgın hastalığın komşusunun büyü yapması nedeniyle gerçekleştiğini düşünerek komşusunun öldürülmesi verilmektedir. Söz konusu iki örnek bakımından da failin insani duygulardan uzak olduğu belirtilmektedir. Yine failin, fuhşu ortadan kaldırmak amacıyla geçimini bu şekilde idame ettirenleri öldürdüğü takdirde canavarca hisle kasten öldürme suçunu işlediği, aynı yorumun dini ya da etnik sebeplerle, bazı toplumsal sinıf ya da gruplara duyulan antipati nedeniyle kasten öldürme suçunun işlendiği hallerde de geçerli olduğu, zira çağdaş ve laik bir toplumda söz konusu nedenlerin barbarlığın göstergesi olduğu da savunulmaktadır ${ }^{44}$.

ETCK döneminde de nitelikli hal olarak öngörülen söz konusu nedenle ilgili olarak mehaz 1889 tarihli İt. CK'nın gerekçesinde kazanç amacıyla değil, kan arzusuyla ve de insanı ürküten kötü yüreklilikle kasten öldürmenin işlenmesi halinde canavarca hissin varlığından bahsedilmiştir ${ }^{45}$. Bu kapsamda canavarca his, insanın hayvanlığını, vahşi hissini ve kan dökmeye yatkınlığını göstermektedir ${ }^{46}$. Ancak 1930 tarihli İt. CK'nın yürürlüğe girmesiyle artık 1889 tarihli İt. CK'dan farklı olarak yalnızca kasten öldürme ve yaralama suçuyla ilgili olarak değil, genel hükümlerde "alçakça ${ }^{47}$ ya da değersiz/yararsız nedenlerle” bir kimsenin öldürülmesi ağırlaştırıcı neden yapılmıştır. Ancak bu neden içinde "canavarca his"sin varlığı da kabul edilmektedir. Bu kapsamda örnek olarak bir kimsenin tanımadığı başka bir kimseyi sesini yükselttiği, ufak nitelikte bir anlaşmazlık yaşadığı, kendisine sigara vermediği, küfrettiği, kötülük yapmak ya da gurur duymak için öldürmesi verilmektedir. $\mathrm{Bu}$ verilen örnekler bakımından da esasında failin öldürmek için bir nedeni vardır ancak bu neden yok denecek boyuttadır. Bu yüzden söz konusu haller failin kötülüğünün ve tehlikeliliğinin yoğunluğu ile suç işleme eğilimini göstermektedir. Canavarca hissin nitelikli hal olarak

\footnotetext{
44 Erman/Özek, s. 39, 40.

45 Selçuk, "Canavarca", s. 468.

46 Majno Ceza Kanunu Şerhi, C. 3, Yargıtay Yayınları No: 8, Ankara 1980, s. 231.

47 Alman hukukunda bir kimsenin diğerine "sahip olamaması" ve başkasının da sahip olmasını engellemek amacıyla öldürülmesi halinde suçun "alçakça saiklerle" öldürme şeklinde kabul edildiği yönünde bkz. Gökcen, Ahmet/Balcı, Murat: Kasten Öldürme Kasten Yaralama Organ ve Doku Ticareti Suçları, 2. Bası, Adalet Yayınevi, Ankara 2015, s. 148, dp. 45.
} 
öngörülmesinin sebebini de failin toplum bakımından gösterdiği tehlikelilik oluşturmaktadır. Zira fail tereddüt etmeksizin, canı istediği için birini seçerek öldürmekte ve böylece mağduru bencilce isteklerinin bir aracı haline getirmektedir. Söz konusu durum potansiyel mağdurlar bakımından da oldukça korkutucu bir etkiye sahip olmaktadır ${ }^{48}$. Başkalarının hayatına ilişkin temel bir saygısızlık ve başkalarının hayatını bir hiç olarak görme söz konusudur $^{49}$. Toplumun korunması ve cezanın önleyici işlevinin gerçekleştirilmesi bu kapsamda etkili olmaktadır ${ }^{50}$. Zira davranışın nedenini açıklamak esasında olanak dahilinde değildir. Nitekim neden, davranışı açıklamak bakımından yetersiz kalmaktadır ${ }^{51}$.

Esasında canavarca hisle öldürmede failin amacının sadece öldürmek için öldürme olduğu, bu kapsamda öldürmekten zevk alma duygusuyla hareket ettiği görülmektedir. Mağdurun şahsıyla ilgili olarak öldürme için bir nedenin bulunmaması, kasten öldürmenin dişında bir amacın olmaması ve öldürmenin bizatihi suç işleme konusundaki menfaati oluşturması söz konusu olmaktadır. Yani "öldürme sevinciyle", bir kimsenin öldürülmesinin nasıl bir şey olacağına ilişkin duyulan merak veya saf kötülük nedeniyle ya da zaman geçirmek ${ }^{52}$ veya eğlenmek için öldürmeden bahsedilebilir ${ }^{53}$. Bu kapsamda basına da yansıyan Ceren Özdemir cinayeti örnek olarak verilebilir $^{54}$. Nitekim fail için hedef alınan mağdurun herhangi bir neden olmaksızın başka bir kimseyle değiştirilmesi mümkündür ${ }^{55}$.

48 Schneider, StGB $\S 211, \mathrm{Rn} .52$.

49 Neumann/Saliger, StGB $\S 211$, Rn. 8.

50 Gökcen/Balcı, s. 147; Artuk/Gökcen/Yenidünya, s. 3009.

51 Selçuk, "Canavarca", s. 472-472, 476-477.

52 Kühl, StGB $§ 211$, Rn. 4.

53 Schneider, StGB § 211, Rn. 49.

54 Akyürek, Güçlü: "YCGK Kararı Işı̆̆ında Canavarca Hisle veya Eziyet Çektirerek Kasten Öldürme Suçu (TCK m. 82/1-b)", Bahçeşehir Üniversitesi Hukuk Fakültesi Dergisi, C. 15, S. 185-186, Ocak-Şubat 2020, s. 15. Nitekim Ceren Özdemir'i öldüren fail, işlediği suçla ilgili olarak alınan ifadesinde "Bir marketten bıçak alıp insan avına çıktım. Çeşitli şahısları takip ederek, bıçak ve tornavida ile öldürmeyi düşündüm. Ancak son anda başkaları karşıma çıkınca gerçekleştiremedim. Olay sabahı, 'Kimi öldürebilirim' diye insan takibine başladım. Karşıma bir bayan çıktı. Takip ederek, evinin bulunduğu binayı öğrendim. Ancak hangi daireye girdiğini görmedim. Bu kızı öldürmeyi çok istedim. Cezaevinden çıkınca adresini tespit etmiş olduğum bayanı öldüreceğim. Caddede kısa boylu bayan gözüme kestirerek takibe başladım. Bazen aramıza mesafe koyup bazen yan yana yürüdüm. Zile bastı. Tam kapıyı kapatacakken 'Bakar mısınız' deyip birlikte apartmana girdim ve bıçakladım. Pişman değilim. Cezaevinden çıkarsam yine insan öldürmeyi düşünüyorum." demiştir. (İlgili haber metni için bkz. https://www.internethaber.com/ceren-ozdemiri-katili-ozgur-arducun-ifadesi-kan- 
Öldürmek için öldürmek ${ }^{56}$, öldürmeden zevk almak ${ }^{57}$, silahını denemek $^{58}$, kan dökmek için öldürmek, kan gördükçe kan dökmeye devam etmek istemek, canavarca hisle öldürmeye örnek olarak verilmektedir. Ayrıca öle-

dondurdu-cikinca-yine-oldurecegim-foto-galerisi-2067890.htm) (Erişim Tarihi: 15.12.2020)

Ancak YCGK benzer bir olayda ise bu ağırlaştırıcı nedeni uygulamamıştır. Nitekim söz konusu karar şu şekildedir: "Olayda sanık 9 yaşındaki maktulü (sigara vereceğinden) bahisle kandirarak belediye parkindan yanına alıp issız mahal olan olay yerine götürmüşür. Orada öldürmek için hiçbir sebep mevcut olmaksızın merhametsizce boğazını sıkıp (hyoid) kemiğini kırdıktan sonra çizmesinin ökçe kısmı ile gaddarca baş ve yüz nahiyelerini tekmeleyerek feci şekilde öldürmesi"ni kasten öldürmenin basit hali olarak kabul etmiştir. YCGK, 520/19, T. 1.2.1988 (Karar metni için bkz. Savaş/ Mollamahmutoğlu, s.4086-4090) Ceren Özdemir cinayetiyle ilgili olarak "canavarca his"sin kabul edilmesi, bahsi geçen ve YCGK'nın 520/19 sayılı kararına konu olan olay bakımındansa "canavarca his"sin kabul edilmemesinin çelişkili olacağı belirtilmelidir. Schneider, StGB § 211, Rn. 49.

56 Öldürme sürecinin kendisi, burada tek öldürme dürtüsünü oluşturmaktadır. Bkz. Kühl, StGB § 211, Rn. 4. "Sanığın, içgüdüsel tatmin amacı ile tanımadığı maktule müteaddit defa büyük bir taş kütlesi ile saldırarak, sirf öldürmüss olmak için öldürdügü, bu doğrultuda failin, canavarca his sevkinden başka kendisini eyleme iten herhangi bir neden mevcut olmaksızın, suçun işleniş biçimi ve eylemin ağırlı̆̆ ile ortaya çıkan kastının, kullandiğı yöntem itibariyle canavarca hisle öldürme suçuna yönelik olduğunun anlaşılması karşısında; TCK.nin 82/1-b maddesi kapsamında hüküm kurulması yerine, suç niteliğinin tayininde yanılglya düşülerek TCK.nin 81. maddesi gereğince kasten öldürme suçundan yazılı şekilde hüküm kurulması usul ve yasaya aykırı olduğundan, İzmir Bölge Adliye Mahkemesince yazll şekilde CMK.nin 280/1-a-c maddeleri uyarınca esastan reddine karar verilmiş olması," Y. 1. CD. E. 2019/3513 K. 2019/5634 T. 18.12.2019

Ancak YCGK benzer bir olayda ise bu ağırlaştırıcı nedeni uygulamamıştır. Nitekim söz konusu karar şu şekildedir: "Oluşa ve dosya kapsamına göre; sanığın, komşusu maktul ile birlikte apartmanın siğınă̆ına indikleri... Sanığın, eşya indiren maktulle birlikte girdiği apartmanın bodrum katında, maktulün, etrafta dağınık şekilde bulunan eşyaların belli bir düzene göre konulmasının uygun olacağın söylediği esnada, depoda bulunan baltanin künt tarafi ile maktulün kafasina vurduğu, daha sonra yere düşen maktule başını gövdeden ayıracak şekilde birçok kez baltayla vurmak suretiyle öldürdüğü olayda; saniğın maktulü öldürme nedeninin tespit edilememesi ve öldürme kastına yönelik çok sayıdaki yaranın tek başına canavarca hisle kasten öldürme suçunun kanıtı sayllamayacă̆l, saniğın canavarca hisle öldürme amaclyla hareket ettiğini gösterir nitelikte delil bulunmadığı, bu şekilde sanığın fiilinin TCK'nun 81. maddesinde düzenlenen kasten öldürme suçunu oluşturduğunun kabulü gerekmektedir.” YCGK E. 2015/1334 K. 2016/317 T. 20.9.2016 (Karar metinleri için bkz. www.kazanci.com) (Erişim Tarihi: 1.12.2020) Söz konusu bu iki kararın birbiriyle çeliştiği ifade edilmelidir. Akyürek, s. 16, 18.

58 YCGK 1-17/1, T. 15.4.1963 T. (Karar metni için bkz. Savaş/Mollamahmutoğlu, s. 4100-4102); YCGK E. 1983/8-64 K. 1983/156 T. 4.4.1983; Y. 1. CD. E. 2017/2099 K. 2019/1046 T. 20.2.2019 (Karar metinleri için bkz. www.kazanci.com) (Erişim Tarihi: 10.12.2020) 
nin acı çekmesinden zevk duymak, bu kapsamda örnek olarak verilmekteyse de burada eziyet çektirerek öldürmenin de söz konusu olabileceği belirtilmelidir. "Canavar" ifadesi failin duygusuzluğunu, "his" ifadesiyse insansı bir durumu anlatmakta olup "canavarca his"ten anlamsızlığın anlaşılması gerektiği de savunulmaktadır. Bu kapsamda nedensiz yere öldürme halinde de canavarca hissin varlığından bahsedilmektedir ${ }^{59}$. Bu kabulün temelinde esasında daha evvel de belirtildiği üzere mehaz kanunda "canavarca his"ten evvel "yalnızca" ifadesine yer verilmesi yatmaktadır. Oldukça anlamsız ya da uzak olarak kabul edilen bir sebebin bulunduğu her durumda dahi "yalnızca canavarca his" söz konusu olmadığından bu ağırlaştırıcı sebep uygulanmamaktadır ${ }^{60}$. Ancak nedensiz yere öldürmek ya da öldürme fiilinin izahının açıklanamadığı hallerde canavarca hissin varlığından bahsedilmemelidir ${ }^{61}$. Nitekim burada insanın gerçekleştirdiği fiilin nedenden yoksun olmayacağı belirtilmelidir. Ayrıca nedensiz yere öldürme halinde failin artık akıl sağlığının da yerinde olmayabileceği, bu nedenle cezayı ağırlaştıran bir neden olarak kabulünün yerinde olmayacağına ilişkin savunmaların dahi yapılması mümkündür ${ }^{62}$. Bu yüzden, nedenin bilinememesi ya da açıklanamaması nedeniyle canavarca hissin varlığı kabul edilmemelidir. Muhtemel nedenler ayrık tutulduğunda failin kişiliği, bu kapsamda örneğin kavgacı ya da zorba bir yapıya sahip olmasıyla söz konusu his açıklanabilir. Yine neden eksikliğinin yanında ayrıca failin geçmişinden yararlanmak suretiyle canavarca hissin varlığı anlaşılmaya çalışılmalıdır ${ }^{63}$. Ancak yapılan tüm bu belirleme ya da tanımlama çalışmalarına karşın yine de nesnel bir ölçütün belirlenmesinin zor olduğu belirtilmelidir.

\section{KASTEN ÖLDÜRME SUÇUNUN "CANAVARCA HISLE" Mİ YOKSA "EZIYET ÇEKTİREREK" Mİ İŞLENDIĞİ SORUNU}

\section{A. Sorunun Nedeni}

TCK'nın 82. maddesinin (b) bendinde ilki "canavarca hisle"; ikincisiyse "eziyet çektirerek" olmak üzere iki ayrı nitelikli hale, aynı bent

59 Toroslu, Nevzat, s. 31. Failin annesini herhangi bir neden olmaksızın öldürmesi, bu kapsamda örnek olarak verilmektedir. Bkz. Arslantürk, Mustafa: Öldürme Suçları Açıklamalı - Örnekli - Notlu - İçtihatlı - Gerekçeli, 2. Bası, Adalet Yayınevi, Ankara 2020, s. 398.

60 Erman/Özek, s. 38.

61 Artuk/Gökcen/Yenidünya, s. 3009.

62 Erman/Özek, s. 38-39.

63 Selçuk, "Canavarca", s. 469. 
altında yer verilmesi eleştirilmesi gereken bir durumdur. Nitekim kasten öldürme suçunun "canavarca hisle" işlenmesi failin sübjektif durumundan, "eziyet çektirerek" işlenmesiyse suçun işlenme yani davranışın gerçekleştirilme şeklinden kaynaklanmaktadır ${ }^{64}$. Bir anlamda "canavarca hisle" öldürmede fail, "eziyet çektirerek" öldürmede ise fiil ön plana çıkmaktadır ${ }^{65}$. Nitekim bir önceki başlıkta da belirtildiği üzere "canavarca his" failin psikolojisiyle $^{66}$ ve faili suça iten içtepiyle yani güdüyle ilgilidir ${ }^{67}$. Bu kapsamda her iki nitelikli hal, birbirinden bağımsızdır ${ }^{68}$. Hükmün gerekçesinde de iki ayrı seçimlik harekete aynı bent altında yer verildiği belirtilmiştir ${ }^{69}$. "Eziyet çektirerek" öldürmede, öldürmenin işleniş şekli itibariyle canavarca gerçekleştirildiğini söylemek mümkündür ${ }^{70}$ ki belki de bu durum dahi söz konusu iki nitelikli halin birbirine karıştırılmasına sebebiyet vermektedir.

Failin "canavarca hisle" kasten öldürme suçunu işlemesine karşın bunu "eziyet çektirerek" gerçekleştirmemesi mümkün olduğu gibi ${ }^{71}$ failin "canavarca hissi" bulunmamasına karşın mağduru "eziyet çektirerek" öldürmesi de mümkündür ${ }^{72}$. Ancak "canavarca hissin" failin davranışlarına aynı zamanda "eziyet çektirerek" öldürme şeklinde yansıması da mümkündür ${ }^{73} \mathrm{ki}$ bu durumda failin ceza sorumluluğu her iki nitelikli hal bakımından söz konusu olacaktır. $\mathrm{Bu}$ halde faile iki kez "ağırlaştırılmış müebbet hapis cezası" değil, bir kez "ağırlaştırılmış müebbet hapis cezası" verilecektir.

64 Özbek/Doğan/Bacaksız, s. 125; Koca, Mahmut/Üzülmez, İlhan: Türk Ceza Hukuku Özel Hükümler, 6. Bas1, Adalet Yayınevi, Ankara 2019, s. 99; Yaşar, Osman/Gökcan, Hasan Tahsin/Artuç, Mustafa: Yorumlu - Uygulamalı Türk Ceza Kanunu, C. 2, 2. Bası, Adalet Yayınevi, Ankara 2014, s. 2659; Özbek, Veli Özer: TCK İzmir Şerhi Yeni Türk Ceza Kanununun Anlamı, C. II, Seçkin Yayıncılık, Ankara 2008, s. 224-225. Ancak, eziyetin failin sübjektif durumundan kaynaklandığı yönündeki farklı görüş için bkz. Centel/Zafer/Çakmut, s. 48; Önder, s. 27; Artuç, Mustafa: Kişilere Karşı Suçlar, 2. Bas1, Adalet Yayınevi, Ankara 2018, s. 183.

Akyürek, s. 15.

Akyürek, s. 9.

Selçuk, "Canavarca", s. 471.

Tezcan/Erdem/Önok, s. 153; Özbek/Doğan/Bacaksız, s. 125; Otacı, Öldürme, s. 490. Gerekçe metni için bkz. Şahin, Cumhur/Özgenç, İzzet: Türk Ceza Hukuku Gazi Külliyat1, 1. Bası, Seçkin Yayıncılık, Ankara 2005, s. 173.

Koca/Üzülmez, s. 99-100.

$\mathrm{Bu}$ kapsamda tesadüf eseri önüne çıkan bir kimseyi öldürmek isteyen failin, bu kimsenin kafasını hedef alarak bir el ateş etmesi ve öldürmesi verilebilir.

72 Olgun, Eser: "Kasten Öldürme Suçunun Türk-Alman Karşılaştırmalı Ceza Hukuku Bakımından İncelenmesi", Marmara Üniversitesi Hukuk Fakültesi Hukuk Araştırmaları Dergisi, Prof. Dr. Nur Centel'e Armağan, C. 19, S. 2, 2013, s. 1646.

Selçuk, "Canavarca", s. 471. 
Ancak hüküm kurulurken söz konusu iki nitelikli halin de olayda bulunduğu belirtilmelidir. $\mathrm{Bu}$ kapsamda örneğin ileride söz konusu nitelikli hallerden biri bakımından af çıkması halinde, diğer neden varlığını devam ettirerek failin bu aftan yararlanmasina engel olunacaktır ${ }^{74}$.

İki ayrı nitelikli hale aynı bentte yer verilmesinin bir diğer nedeni olarak yine iki ayrı nitelikli hale ETCK'nın 450. maddesinin (3). bendinde ${ }^{75}$ birlikte yer verilmesinin de etkili olduğu belirtilmelidir. Ancak kasten öldürme suçuyla ilgili olarak örneğin bu suçun "tasarlayarak" işlenmesi nasıl ki TCK'nın 82. maddesinin (a) bendinde bağımsız ve tek başına ayrı bir nitelikli hal olarak öngörülmüşse benzer düzenlemenin (b) bendinde öngörülen söz konusu nitelikli haller için de gerçekleştirilmesinde fayda vardır.

Her iki nitelikli halde de faildeki ahlaki kötülüğün yoğunluğu ve insana has duygulardan yoksunluk cezanın ağırlaştırılmasını gerektirmektedir ${ }^{76}$. Nitekim "canavarca hisle" öldürmedeki temelsizlik ve mantıksızlık cezanın ağırlaştırılması bakımından meşruiyetini göstermektedir ${ }^{77}$. Yine "eziyet çektirerek" öldürmede, failin değerlere olan kayıtsızlığının ve de nefretinin suçu barbarca işlemesine neden olduğu ve failin bu tehlikeliliğinin daha ağır bir şekilde cezalandırmanın gerekçesini oluşturduğu görülmektedir ${ }^{78}$. Ancak her iki nitelikli hale aynı bent altında yer verilmesinin çalışmanın ilerleyen bölümlerinde de açıklanacağ üzere "canavarca his" ifadesinden, neyin anlaş1ması gerektiği hususuna ilişkin öğretide ve uygulamada herhangi bir birliğin sağlanması bakımından engel oluşturduğu görülmektedir.

Kasten öldürme suçunun "canavarca hisle" işlenmesiyle, suçun gerçekleştiriliş şeklinin "canavarca" olması aynı şey değildir ki birbirine en çok

74 Yaşar/Gökcan/Artuç, s. 2654-2655.

75 Bu hükme göre "öldürmek fiili: ... canavarca bir his sevki ile veya işkence ve tazip ile ika edilirse... Fail, "ağırlaştırılmış müebbet ă̆ır hapis" cezasına mahkûm edilir." Söz konusu hükümde 2004 yılında ve yayım tarihinde yürürlüğe giren 5218 sayılı "Ölüm Cezasının Kaldırılması ile Bazı Kanunlarda Değişiklik Yapılmasına İlişkin Kanun"un 1. maddesi (bkz. 25529 sayılı 21.7.2004 tarihli Resmî Gazete) ile gerçekleştirilen değişiklikten evvel, idam cezası öngörülmekteydi.

"Tazip” köken olarak Arapçadan gelmektedir ve "sıkıntıya sokma, üzme” (bkz. Türk Dil Kurumu, s. 2292), "eziyet etme, boşuna yorma" anlamına gelmektedir. Bkz. Devellioğlu, s. 1217.

76 Dönmezer, s. 51; YCGK, E. 2017/659, K. 2018/668, T. 20.12.2018 (Karar metni için bkz. https:/www.lexpera.com.tr/ictihat/yargitay/ceza-genel-kurulu-e-2017-659-k-2018668-t-20-12-2018) (Erişim Tarihi: 6.12.2020); Koca/Üzülmez, s. 99.

Schneider, StGB § 211, Rn. 52.

78 Selçuk, "Canavarca", s. 471. 
bu iki hususun karıştırıldığı görülmektedir. Failde "canavarca his" bulunmamasına karşın suçun "canavarca" gerçekleştirilmesi halinde "eziyet çektirerek" öldürmeden bahsedilmesi gereklidir" . Örnek olarak kendisine küfreden (A)'y1, (B)'nin küçük küçük parçalar halinde doğrayarak öldürmesi halinde (B)'yi öldürmeye yönlendiren his, "canavarca" değildir ${ }^{80}$. Ancak suçun işleniş şekli "canavarca"dır. Buna karşın yine de uygulamada kasten öldürme suçunun "canavarca hisle" işlenmesiyle "eziyet çektirerek" işlenmesi arasındaki farkın net bir şekilde ortaya konulmadığ görülmektedir ${ }^{81}$.

79 Erman/Özek, s. 39; Özen, s. 136.

“Sanık ... ile arkadaşı olan maktul ...'un olay günü Çeşme ilçe merkezinde buluşup marketten alkol aldıktan sonra, sanık ...'nin yaklaşık bir aydan beri kalmakta olduğu bağ evine gittikleri ve alkol almaya başladıkları, içkilerinin bitmesi üzerine maktulün, sanıktan ilçe merkezine giderek rakı almasını istediği ve konuşma esnasında sanığa küfrettiği, sanığın içki almaya gitmeyi kabul etmemesi üzerine maktulün ısrar ederek küfürlü konuşmaya devam ettiği, maktulün yoğun ısrarı üzerine saniğın, maktulü küfretmemesi hususunda uyardıktan sonra ilçe merkezine gittiği, ilçe merkezinde önce marketten aldiğı biraları içen sanığın, bir bara giderek orada da alkol aldıktan sonra rakı almaya parası yetmediği için şarap alarak gece yarısından sonra bă̆ evine döndüğ̈̈ ve uyumakta olan maktulü uyandırıp şarap aldı̆̆ını söylediği, sanı̆̆ın rakı yerine şarap getirdiğini gören maktulün, aksi kanttlanmayan savunmaya göre saniğa kizdiğ ve sinkaflı sözlerle küfrettiği, bunun üzerine sanı̆̆ın maktule iki tokat attı̆̆l, maktulün de bıçak ile sanı̆̆ın üzerine yürüdü̈̆̈̈, maktulün elinden bıçă̆ alan sanığın, maktulü 23 bıçak darbesiyle yaraladı̆̆g, maktulün kesici delici alet yaralanmasına bağll iç organ ve büyük damar kesisi ile gelişen kanama sonucu öldüğ̈̈ olayda; maktulün vücudunda çok sayıda delici kesici alet yarası bulunmakta ise de, sanık ve maktulün gece yarısı yapmış oldukları telefon görüşmelerinin saati ve tanık beyanlarına göre sabah erken vakitte sanığın bă̆ evinden ayrllarak otogara gittiği göz önüne alındiğında, saniğın eylemini sirf eziyete neden olacak şekilde uzun bir zaman dilimine yaymadiğının anlaşılması, olayın aşırı derecede alkollü olan sanık ile maktul arasında geçen küfürlü konuşmalar ve maktulün sanıktan içki alması için ısrarı nedeniyle çıkan tartışmada, maktulün elindeki bıçakla sanığa doğru hamle yapması sonucu gerçekleşmiş olması, dolayısıyla sanığın önceden kendisinde mevcut olan bir his, düşünce nedeniyle değil de, sanığın maktule olan kızgınlı̆̆ı nedeniyle o esnada ortaya çıkan ani bir kastla eylemini gerçekleştirmesi, sanı̆̆ın çok sayıdaki bıçak darbesinden ibaret eyleminin tek başına canavarca hisle veya eziyet çektirerek kasten öldürme suçunun kanıtı sayılamayacak oluşu ve sanığın canavarca hisle veya eziyet çektirerek öldürme amactyla hareket ettiğini gösterir nitelikte delil bulunmaması bir bütün olarak değerlendirildiğinde; saniğın eylemini, maktulden kaynaklanan ve haksız tahrik oluşturan söz ve davranışlara tepki olarak gerçekleştirdiği ve eyleminin TCK'nın 81/1. maddesinde düzenlenen kasten öldürme suçunu oluşturduğunun kabulü gerekmektedir." YCGK, E. 2017/659, K. 2018/668, T. 20.12.2018 (Karar metni için bkz. https://www.lexpera.com.tr/ictihat/yargitay/ceza-genel-kurulu-e-2017659-k-2018-668-t-20-12-2018) (Erişim Tarihi: 6.12.2020) 


\section{B. Öğretinin ve Uygulamanın Soruna Yaklaşımı ve Bu Yaklaşımın Eleştirisi}

Yargitay, "canavarca hisle" öldürmeyi "sırf öldürmüş olmak için öldürmek, ölenin acı çekmesinden zevk duymak için öldürmek" şeklinde örneklendirmekteyken, eziyet çektirerek öldürmeyi ise "öldürme eyleminden önce öldürülecek olana karşı azap ve işkence yapmayı hedef tutan, ölümü meydana getirmek bakımından zorunlu olmayan vahşice davranışlarda bulunmak ${ }^{, 82}$ şeklinde tanımlamaktadır ${ }^{83}$. Ayrıca, Yargıtay her iki nitelikli hal bakımından "sadist bir duygu ve düşüncenin" fiile hakim olduğunu ifade etmektedir ${ }^{84}$.

Yargıtay, sanığın evli olmasına karşın bir süre birlikte yaşadığı kişinin geçimini sağlamak için başka kimselerle cinsel ilişkiye girmemesini istemesi, ancak bunun karşı tarafça kabul edilmemesi üzerine karşı tarafın 18 bıçak darbesiyle birlikte vajinasına tuzluk sokmasını "canavarca his" olarak kabul etmiştir ${ }^{85}$. Ancak Yargitay burada neden canavarca hissin var oldu-

“Ölen Hamid'in sanığın karısını kaçırarak onunla cinsi münasebette bulunması olaydan bir süre önce bu kasit altında sanığın evine girmesi yine bu maksatla teklifte bulunmast karşısında saniğın bu suçu işlemesi onun işkence ve tazip kastiyle bu suçu işlediğini kabule engel teşkil etmez. Bu hal ancak sanık hakkında ă̆ır ve haksız bir kışkırtma sayılabilir ki bu da mahkemece gözetilmiştir. Yoksa sanı̆̆ın ölenin her türlü direnmesini elindeki keser sapıyla, başına kollarına vurarak yaralar açıp kırdıktan sonra elindeki çakı ile onun bilfarz boğazını keserek bir an önce ölmesini sağlaması mümkün iken Hamid'in öldürülmesi bakımından hiç de zorunluk olmadığ halde onun kollarının kemiklerini kırmak, kilotunu slyırarak erkeklik aletini kesmek, sercine birkaç kez bıçak saplamak yollarıyla onu yavaş yavaş ölüme doğru sürüklediği ve dolaylsıyla 450. maddenin 3. bendinde yazıl işkence ve tazip kasdiyla hareket ettiği yolundaki mahkemenin kabulü kanuna uygundur. Zira bu davranışlar, yalnız öldürme kasdının sonucu sayılmayıp ondan çok ileri giden bir kasdın sonucu niteliğinde bulunan vahşice davranışlar olduğu" YCGK'nın 1/17 E. 17 K. 15.4.1963 tarihli karanı için bkz. YCGK E. 1981/1169 K. 1981/288 T. 6.7.1981 (Karar metni için bkz. www.kazanci.com) (Erişim Tarihi: 1.12.2020)

83 Y. 1. CD. E. 2010/2749 K. 2010/7581 T. 29.11.2010; Y. 1. CD. E. 2016/748 K. 2017/ 1103 T. 5.4.2017 (Karar metinleri için bkz. www.kazanci.com) (Erişim Tarihi: 5.12.2020)

84 YCGK E. 1987/99 K. 1987/276 T. 11.5.1987 (Karar metni için bkz. www.kazanci.com) (Erişim Tarihi: 6.12.2020)

85 Y. 1. CD. E. 2009/6525 K. 2010/3023 T. 27.4.2010 (Karar metni için bkz. www.kazanci.com) (Erişim Tarihi: 5.12.2020) Yargıtay, yine benzer şekilde bir diğer kararında, mağdurun içkinin etkisiyle sanığa "ayı" demesi, bunun üzerine sanıkla mağdurun tartıştıkları, sanığın rakı şişesini mağdura vurmaya başladığı, daha sonra "yere düşürdüğ̈̈ maktülü ters çevirerek pantolonunu ve külotunu slyırarak kabalarda 20 cm.ye kadar uzayan pek çok yaralar husule getirmesi ve anüsünü parçalayacak biçimde şişe sokması, sırf öldürmüş olmak için öldürmek ve ölenin acı çekmesinden zevk duymak 
ğunu yeterince gerekçelendirmemiştir. Failin gerçekleştirdiği bıçak darbeleri öldürmenin gereği olup sayısındaki fazlalık, sanığın saikini ortaya koymak bakımından yeterli değildir ${ }^{86}$. Ancak söz konusu durumun cezanın üst sınırdan belirlenmesi bakımından gerekçe oluşturabileceği belirtilmelidir ${ }^{87}$. Hatta darbelerin ve yaraların sayısındaki fazlalık, suçun "eziyet çektirerek" işlendiğinin kabulünde dahi tek başına yeterli değildir. Nitekim Yargıtay'ın da bu yönde kararlarının bulunduğu görülmektedir ${ }^{88}$. Örneğin Yargitay 2017/1103 say1lı kararında failin mağdura karş1 gerçekleştirdiği 18'i öldürücü nitelikte toplamda 72 bıçak darbesini ne "canavarca hisle" ne de “eziyet çektirerek" öldürme kapsamında değerlendirmiştir ${ }^{89}$. Yine Yargıtay

için yapılan ve zorunlu olmayan vahşî hareketler olarak kabul edilmiştir" diyerek "canavarca hisle ve eziyet çektirerek" kasten öldürme suçunun varlığını kabul etmiştir. YCGK 67/147, T. 24.4.1978 (Karar metni için bkz. Savaş/Mollamahmutoğlu, s. 40974098) Yine anüse şişe sokarak öldürmenin "canavarca hisle" öldürmek olduğu yönündeki görüş için bkz. Koca/Üzülmez, s. 100.

86 Benzer yönde bkz. Gözübüyük, Abdullah Pulat: Alman, Fransız, İsviçre ve İtalyan Ceza Kanunlariyle Mukayeseli Türk Ceza Kanunu Açıklaması, C. IV, Sevinç Matbaası, Ankara (Tarihsiz), s. 314. Çok sayıda bıçak darbesiyle öldürmenin canavarca hisle öldürme olduğu yönündeki farklı görüş için bkz. Koca/Üzülmez, s. 100.

87 Özbek/Doğan/Bacaksız, s. 126-127.

88 “Sanık ...'ın maktulü, 12 'si öldürücü 47 bıçak darbesiyle yaralayarak öldürdüğü anlaşılan olayda; pek çok öldürücü nitelikte yara ika edilmesinin tek başına canavarca hisle ya da eziyet çektirerek işlendiğini kabule yeterli bulunmadĭgl, canavarca hisle öldürme, sırf öldürmüş olmak için öldürme, ölenin acı çekmesinden zevk duymak için öldürme olup, eziyet çektirerek öldürme ise ölümü meydana getirme bakımından zorunlu olmayan ve ölüme takaddüm eder vahşice hareketler olup saniğın öldürme kastının yanında işkence ya da eziyet çektirme kastının da bulunması gerektiği, sırf ölüm neticesini almak için tehevvürle maktulün boyun ve gövde kısmına bıçakla çok sayıda darbenin yapıldığı, somut olayda ise maktulün aldığı bıçak darbeleri sonucu hayatını kaybettiği göz önünde bulundurulduğunda sanığın canavarca hisle ya da eziyet çektirerek öldürme amactyla hareket ettiğini, kabule yeterli her türlü kuşkudan uzak yeterli kesin kanıt bulunmadı̆̆ gözetilmeyerek TCK'nin 81/1 maddesi yerine TCK.nin 82/1-b maddesiyle uygulama yapılması," Y. 1. CD. E. 2017/3654 K. 2019/4942 T. 13.11.2019 (Karar metni için bkz. www.kazanci.com) (Erişim Tarihi: 7.12.2020); "Sanığın kesici ve delici aletle sekizi öldürücü olmak üzere toplam 16 adet yara oluşturacak 16 yaş içerisinde bulunan çocuk maktulü öldürdüğ̈̈ olayda, sanı̆̆ın öldürmek kastıyla otopside belirtilen yaraları meydana getirmesinin canavarca hisle ve eziyet çektirerek öldürme amacını güttüğ̈̈nü tek başına ortaya koymayacağı gibi, bu amaçla hareket ettiğine ve ayrıca maktulün beden ve ruh bakımından kendisini savunamayacak durumda bulunduğuna ilişkin dosyada kesin inandırıcı kanıtlar bulunmadiğı anlaşıldiğından" Yargıtay 1. CD. 2020/5110 E. 2011/906 K. 22.2.2011 T. (Karar metni için bkz. Yaşar/Gökcan/Artuç, s. 26642665, dp. 1586)

89 Y. 1. CD. E. 2016/748 K. 2017/1103 T. 5.4.2017 (Karar metni için bkz. www.kazanci.com) (Erişim Tarihi: 5.12.2020) 
başka bir kararında failin mağduru 13 bıçak darbesinin ardından mağdurun kafasına taşla vurarak öldürmesini de ne "canavarca his" ne de "eziyet çektirerek" öldürmek olarak kabul etmiştir". Öldürme neticesinden öteye gitmeyen ve bu kapsamda yalnızca ölüm neticesini meydana getirmeye yönelik davranışlar ile acı çektirmek şeklinde bir amaç taşımayan davranışlar eziyet çektirmek kapsamında değerlendirilemez ${ }^{91}$. Bu nedenle failin mağ-

90 “aralarında arkadaşlık ilişkisi bulunan sanıklar I. ve E. ile maktul S. 'ın, olay tarihinde olayın meydana geldiği köprü altına giderek birlikte alkol aldıkları, burada sanıklardan E. 'nin maktule, M. isimli kızla olan ilişkisini bitirmesini söylediği, maktulün bunu kabul etmediği, bunun üzerine sanık I.' in 13 biçak darbesi ve taşla başına vurmak suretiyle maktulü öldürdüğü, diğer sanık E. 'nin ise köprü üstüne çıkarak gözcülük yapmak suretiyle yardım eden olarak suça katıldı̆̆ olayda, sadece öldürme kastına yönelik çok sayıdaki bıçak darbesi ve taşla vurmanın canavarca hisle veya eziyet çektirerek öldürme sucuna kanıt sayllamayacağı, suçun bu saikle işlendiğini gösterir kesin ve inandırıcı delillerin de bulunmadı̆̆ının görülmesi karşısında, suç tarihide nazara alınarak, sanık İskender hakkında 5237 Sayılı T.C.K.un 82/1-e, 31/3 maddeleri ile 765 Sayıl T.C.K.nun 448. 55/3 maddeleri arasinda, sanık E. hakkında 5237 Sayıl T.C.K.nun 82/1-e, 39/1, 31/3 maddeleri ile 765 Sayll T.C.K.nun 448, 65/3, 55/3 maddeleri arasinda yaplacak karşılaştırma neticesi lehe yasanın belirlenmesi gerektiğinin düşünülmemesi, ”Y. 1. CD. E. 2011/400 K. 2011/1222 T. 3.3.2011 (Karar metni için bkz. www.kazanci.com) (Erişim Tarihi: 6.12.2020)

"maktul kardeşiyle beraber toprağa gömdükleri paranın yerinde olmaması üzerine

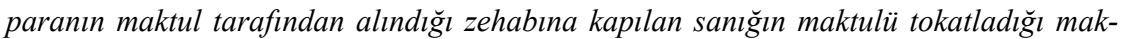
tulünde çakı bıçă̆ı ile sanı̆̆ dizinden yaraladı̆̆ı, yara etkisinde kalan sanık maktulü çakı bıçağıyla karın ve sırtındaki müteaddit darbelerle yaralayarak yere düşürüp eve kaçtı̆̆ anlaşılmaktadır. Kardeşinin ölüp ölmediğini anlamak cesedi ve suçu gizlemek kararıyla evden naylon bir torba alarak olay yerine gelmiştir. Yaralı kardeşinin boynunu sol kulak memesinden başlayan ve orta hatta kadar devam eden 5 santim derinlik ve 12 santim uzunlukta keserek öldürmüş cesedi torbaya koyarak gizlemiştir. Otopsi raporuna göre asıl ölüm nedeni boynundaki kesiktir. Karın ve sırttaki bıçak yaraları ölümü kolaylaştırmıştır. Bu oluşa göre sanığın öldürme gaye ve niyetinden daha öteye giden özel bir amaç ve kasıtla yani canavarca his, işkence ve tazip gibi özel kastla hareket ettiğini kabul eden yerel mahkeme uygulamasinda yasal isabet bulunmamaktadir." YCGK, 1-110/627, 7.6.1982 T. (Karar metni için bkz. Savaş/Mollamahmutoğlu, s. 4092-4093); "Olayımıza baktığımızda, sanıklarla öldürülen arasında kıyasıya bir kavganın başladığg; çok güçlü ve kuvvetli bulanan öldürenle baş edemeyeceklerini anlayan sanıkların diğer sanıklar Tuncay Akay ve Harun Kutsal'dan ip istedikleri, sanık Haşmet Sinan'ın bu arada eline geçirdiği keserle öldürülenin başına ve yüzüne vurmaya başladığ ve getirilen iple öldürüleni bağlayarak Çoşkun ile birlikte boğazını kesmek suretiyle öldürdükleri, anlaşılmıştır. Açılklanan şu oluşa ve otopsideki bulgulara göre sanıkların öldürme sonucunun almaktan öteye giden ve işkence tazip sayllacak; sirf öldürülene eza verme ve kendilerini bu suretle tatmin etme yönünden davranışlart saptanamadiğından hunharca olsa dahi bu tür icranın işkence ve tazip olarak kabulünde isabet yoktur." YCGK E. 1987/99 K. 1987/276 T. 11.5.1987 (Karar metni için bkz. www.kazanci.com) (Erişim Tarihi: 6.12.2020); "Sanıkların, başka bir saikin etkisinde 
duru birden çok darbeyle öldürmesi bizatihi "eziyet çektirerek" öldürmenin varlığını göstermez ${ }^{92}$. Ancak fail "eziyet çektirerek" mağduru öldürürse, söz konusu nitelikli halin uygulama alanı bulmasından bahsetmek gereklidir ${ }^{93}$. Eziyet çektirme kapsamında yer alan davranışların mağdurun ölümünden evvel gerçekleşmesi gereklidir ${ }^{94}$. Ancak az evvel bahsi geçen ve mağdurun 18 bıçak darbesiyle birlikte vajinasına tuzluk sokulması olayında, tuzluğun sokulmasının öldürmeden önce mi yoksa sonrasında mı gerçekleştiği araştırılmamıştır". Bunun ölümden sonra gerçekleştirilmesi halinde zaten "canavarca his"ten bahsedilemez, öncesinde gerçekleştirilmesi halindeyse yine “canavarca his"ten değil "96 "cinsel saldırı" suçundan bahsetmek olanaklıdır".

kalmaksızın sırf ölüm neticesini alabilmeye yönelik olarak önce jiletle boynunu kestikleri maktulü, daha sonra ayakkabı bağıyla boğup ardından da atkl ile ăgaca asmaktan ibaret eylemleri canavarca hisle öldürme suçunu oluşturmayacağının gözetilmemesi" Y. 1. CD. 6300/2131 11.4.2011 T. (Karar metni için bkz. Gökcen/Balcl, s. 151) Ancak Yargitay'ın bu son kararında "eziyet çektirerek" kasten öldürme yerine "canavarca hisle" kasten öldürmeyi tartıştığı ve suçun işleniş şeklinden hareketle bu karara vardığ 1 görülmektedir.

92 Tezcan/Erdem/Önok, s. 156; Özbek/Doğan/Bacaksız, s. 126. "olay günü alkol ve esrar kullanan sanığın maktûlü 26 adedi öldürücü nitelikte olmak üzere toplam 29 bıçak darbesi ile öldürdüğ̈̈ olayda; pek çok öldürücü nitelikte yara ika edilmesinin tek başına suçun canavarca hisle ya da eziyet çektirerek işlendiğini kabule yeterli bulunmadığ " Y. 1. CD. E. 2010/2749 K. 2010/7581 T. 29.11.2010 (Karar metni için bkz. www.kazanci.com) (Erişim Tarihi: 5.12.2020)

93 Yaşar/Gökcan/Artuç, s. 2664-2665.

94 YCGK 1-17/1, T. 15.4.1963 (Karar metni için bkz. Savaş/Mollamahmutoğlu, s. 41004102)

95 "Eziyet çektirerek öldürme, ölümü meydana getirmek için bakımından zorunlu olmayan ve ölüme takaddüm eder vahşice hareketler olup sanığın öldürme kastının yanında işkence ve azap çektirme kastının da bulunması gerekir. Yalnız öldürme kastını gerçekleştirmek için yapılan eylemler eziyet çektirme niteliğinde değildir. Olayda sanı̆̆ın maktulün baş kısmına yönelik bıçak darbeleri sonucu oluşan yaralar yanında să̆ gözünü ölmeden önce bu kast ile çıkardı̆̆ı sabit olmadığından 5237 Sayılı TCK.nun 81. maddesi yerine 82/1-b madde ile cezalandırlmasi" Y.1. CD. 7654/9171 T. 6.12.2007 (Karar metni için bkz. Gökcen/Balcı, s. 156-157, dp. 63)

96 Ancak Yargitay, "maktulün anüsüne sokulan sert cismin ölüm nedeni olup olmadiğı ve ölüme tesir edip etmediği sorulup alınacak mütalaa sonucuna göre” sanı̆̆ın canavarca hisle kasten öldürme suçunu işlediğinin kabulünün gerektiği görüşüne sahiptir. Bkz. Y. 1. CD. E. $1983 / 1737$ K. $1983 / 2171$ T. 21.6.1983 (Karar metni için bkz. www.kazanci.com) (Erişim Tarihi: 10.12.2020)

97 Bu yöndeki karşı oy gerekçesi için bkz. Y. 1. CD. E. 2009/6525 K. 2010/3023 T. 27.4.2010 (Karar metni için bkz. www.kazanci.com) (Erişim Tarihi: 5.12.2020) 
Esasında burada Yargıtay fiilin işleniş şeklinden, failin saikine gitmiş olup bu belirleme sorunludur ${ }^{98}$.

"Eziyet ${ }^{99}$ çektirerek" öldürmeden anlaşılması gerekenin ne olduğuyla ilgili olarak eziyet suçunun kaleme alındığ 1 TCK'nın 96. maddesine bakmakta fayda olsa da söz konusu maddede herhangi bir tanıma ya da açiklamaya yer verilmediği görülmektedir ${ }^{100}$. Ancak bu hükmün gerekçesinde bir kimseye eziyet etmekten "bir kişiye karşı insan onuruyla bağdaşmayan ve bedensel veya ruhsal yönden acı çekmesine, aşağılanmasına" neden olacak davranışların anlaşılması, ayrıca bu davranışların "ani olarak değil, sistematik bir şekilde ve belli bir süreç içinde" işlenmesi gerektiği belirtilmiştir ${ }^{101}$. "Eziyet" suçunda fail, mağdurun vücut dokunulmazlığını ihlal etmek, sağl1ğını bozmak, aşağılamak, onurunu kırmak amacıyla davranışta bulunmaktayken, "eziyet çektirerek" öldürme suçunda fail eziyete ölüm neticesini elde etmede araç olarak başvurmaktadır ${ }^{102}$. Ayrıca "eziyet çektirerek" öldürmede failde mağdurun acı ve ızdırap çekmesine yönelik bir amaç da bulunmak$\operatorname{tad}^{103}$.

Öğretide "eziyet çektirerek" öldürmede, failin mağduru anında öldürme imkanı varken ve bu nedenle ölüm neticesini gerçekleştirmek için zorunlu olmayan $^{104}$ ancak mağdura acı ve ızdırap vermek amacıyla davranışlarını

98 Tezcan/Erdem/Önok, s. 155-156.

99 Eziyet, sözlükte “zulüm”, “sıkıntı veya güçlük” şeklinde tanımlanmaktadır. Bkz. Türk Dil Kurumu, s. 844.

100 Akyürek, s. 15.

101 Süreklilik arz eden eziyet, mağdurun psikolojisi ve ruh sağlığı üzerinde tahrip edici etki doğurmaktadır. Gerekçe metni için bkz. Şahin/Özgenç, s. 192.

102 Centel/Zafer/Çakmut, s. 46, dp. 118.

103 Önder, s. 28. "Canavarca hisle öldürmenin, sırf öldürmüş olmak için öldürme, ölenin acı çekmesinden zevk duymak için öldürme, eziyet çektirerek öldürmenin ise ölümü meydana getirme bakımından zorunlu olmayan ve ölüme takaddüm eder vahşice hareketler olup, öldürme kastının yanında işkence ya da eziyet çektirme kastının da bulunması gerektiği, somut olayda ise sanı̆̆ın işlemeyi kastettiği yağma suçu için önce maktulenin başına künt cisimle vurup bayılttıktan sonra bağırmasını önlemek için ağzına bez parçaları sokmak ve devamında çok sayıda bıçak darbesiyle maktuleyi öldürdü̈̆̈̈ nazara alındiğında, saniğın canavarca hisle ya da eziyet çektirerek öldürme amacıyla hareket ettiğini kabule yeterli her türlü kuşkudan uzak kesin deliller bulunmadiğı halde, sanık hakkında TCK'nin 82/1. maddesinin " $h$ " bendi ile uygulama yapılmast yeterli iken, ayrica uygulama yeri bulunmayan aynı maddenin " $b$ " bendinin de uygulanması, "Y. 1. CD. E. 2019/3412 K. 2020/52 T. 14.1.2020 (Karar metni için bkz. www.kazanci.com) (Erişim Tarihi: 12.12.2020)

104 "keskin bir aletle ve zor kullanarak oluşturulmuş 33 yara bulunduğu, yaraların hepsinin canliyken oluşturulduğu, bu durumda tabii olmayan şiddet kullanma sonucu iç ve dış 
tekrarlaması ve ölüm neticesini yavaş yavaş belli bir süreç içerisinde gerçekleştirmesinin söz konusu olduğu ifade edilmektedir ${ }^{105}$. Burada fail, mağdurun acı çekmesinden zevk almak amacıyla değil, mağdura acı vermek amacıyla eziyeti gerçekleştirmektedir ${ }^{106}$. Yani öldürmek için gerekenin ötesinde bir davranışın gerçekleştirilmiş olması gereklidir ${ }^{107}$. Nitekim her bir kasten öldürme suçu mağduru üzerinde mahiyeti gereği acı ve 1zdırap meydana getirir $^{108}$. Bu kapsamda failin mağduru öldürebilmek için mağdura birkaç el ateş etmesi ya da birden çok bıçak darbesi gerçekleştirmesi "eziyet çektirerek" öldürme değildir ${ }^{109}$. Yine daha evvel de belirtildiği üzere faille mağdur arasında ölüm neticesinin gerçekleşmesine yönelik mücadele esnasında gerçekleştirilen davranışlar eziyet çektirme olarak kabul edilmeme$\operatorname{lidir}^{110}$.

kanamaya bă̆lı olarak ölümün meydana geldiği, yaraların niteliğine bakıldiğında; uzun müddet vücudun yaşamsal önemi olan kısımlarına delici ve kesici aletin israrla batırldiğı bu yaralara rağmen ölenin bir süre daha yaşadı̆̆ı öte yandan ölmeden önce cinsel ilişkide bulunduğu... Ölenin küçük yaşta ve zayıf yapıda bir kız çocuğu olduğu, güçlü kuvvetli bulunan sanığa direnemeyecek bir durumda bulunduğu halde, sanık yaşamsal bölgelerde, vuracağı bir veya birkaç darbe ile sonucu alabilecek durumda iken; yaşamsal olan yada bu nitelikte bulunmayan değişik bölgelerine yüzeysel veya derin çok sayıda yaralar açarak ölene işkence veren zaman içinde süren vahşiyane davranış ve icrada bulunmuştur. Sanığın bu yaralama biçimi sırf ölene açı çektiren, öldürmek için yapılan zorunlu olmayan hareketlerdir. Bu itibarla TCK.nun 450/3. maddesi koşulları da mevcut görülmüs olmakla, Yerel Mahkeme direnme hükmü yerindedir ve onanmasına karar verilmelidir." YCGK E. 1988/1-235 K. 1988/360 T. 17.10.1988 (Karar metni için bkz. www.kazanci.com) (Erişim Tarihi: 15.12.2020)

105 Önder, s. 28; Artuk/Gökcen/Yenidünya, s. 3012; Gökcen/Balcı, s. 154-155; Centel/ Zafer/Çakmut, s. 48. "El ve ayak parmaklarlyla tenasül organlarına cereyan vermek, ayakları demire dayalı ve havada, başları yerde, elleri arkasında olacak şekilde durdurmak, yere düşeni dövmek, başına tekme atmak, hayaları kıvırmak, penisinden tutup sağa sola çekiştirmek, su havuzuna başını sokup havasız bırakmak, içine çok miktarda tuz konulan sulu bir bulamacı coplamak ve dövmek suretiyle direnmeyi kırıp kusturuncaya kadar zorla yedirmek, bir kaptan diğer bir kaba su boşaltarak su arzusunu kamçılamak suretiyle merkezi sinir sistemi kanaması ve aşırı tuzlu bulamacın meydana getirdiği elektrolit denge bozukluğuna bağlı beyin harabiyeti sonucu ölüme sebebiyet vermek"ten (YCGK, 64/156, 4.4.1983) bahsederek Yargıtay'ın bazı davranışları "eziyet çektirerek” öldürme kapsamında örnek vererek açıkladığı yönünde bkz. Erman/Özek, s. 39-40, dp. 89.

Artuç, s. 189

107 Özbek/Doğan/Bacaksız, s. 127.

108 Centel/Zafer/Çakmut, s. 48.

109 Önder, s. 28.

110 Toroslu, Nevzat, s. 31. 
Eziyet oluşturan davranışın burada muhakkak maddi mi ${ }^{111}$ olması gerektiği yoksa manevi nitelikte olmasının da mümkün olup olmadığı hususu tartışmalıdır. Manevi olmasının mümkün olduğu zira "İşkenceye ve Diğer Zalimane, Gayrinsani veya Küçültücü Muamele veya Cezaya Karşı Birleşmiş Milletler Sözleşmesi”"nde işkencenin “fiziki veya manevi ă̆ır acı veya ızdırap veren bir fiil" olarak tanımlandığ 1 görülmektedir ${ }^{112}$. Bu kabulde, ayrıca bedene doğrudan doğruya ya da dolaylı olarak etki etmemesine karşın akıl ve ruh sağlığında önemli bir ızdıraba yol açan davranışların da işkence olarak kabul edilmesi ve de ETCK döneminde "eziyet çektirerek" öldürmenin karşıllı̆ 1 olarak "işkence ve tazip”te bulunmak suretiyle öldürmenin bulunması da etkili olmaktadır. Bu kapsamda her ne kadar mağdur tek darbede öldürülse de ölümünden evvel gözü önünde aile üyelerine karşı insani olarak nitelendirilemeyen davranışlarda bulunulması örnek olarak verilmektedir $^{113}$. Ancak Yargitay 1. CD. 2018/1213 sayılı kararında eziyet çektirerek öldürme bakımından "ve" bağlacı kullanmak suretiyle acının "maddi ve manevi” olmasından bahsetmiştir ${ }^{114}$. Al. CK'nın 211. paragrafının 2. fikrasında "eziyet çektirerek" öldürmenin karşılığı olarak "ac1 çektirmek" suretiyle öldürmeden bahsedilmiş olup söz konusu hükmün kapsamında mağdurun acı içinde veya fiziksel yahut ruhsal bir ızdırap çektirilerek öldürülmesi yer almaktadır ${ }^{115}$. Bu kapsamda eziyet oluşturan davranışın manevi nitelikte olması mümkündür. Zira elverişli olduğu takdirde manevi nitelikte olması halinde eziyet çektirerek öldürmenin varlığının kabul edilmesine engel bir durum bulunmamaktadir.

"Eziyet çektirerek" öldürmede bir diğer tartışmalı hususu davranışın tekrarlanmasının zorunlu olup olmadığı meselesi oluşturmaktadır. Bu

111 Dönmezer, s. 52; Koca/Üzülmez, s. 101; Özbek, s. 226. Örneğin mağdura hakaret edilmek suretiyle öldürmenin gerçekleştirilmesinin bu kapsamda değerlendirilemeyeceği, bu nedenle de "eziyet çektirerek" öldürmenin tanımlanabilmesi için TCK'nın 96. maddesinden yararlanmanın mümkün olmadığı belirtilmektedir. Bkz. Özbek/Doğan/ Bacaksiz, s. 127-128.

112 Sözleşme metni için bkz. 19895 sayılı 10.8.1989 tarihli Resmî Gazete.

113 Erman/Özek, s. 39-41.

114 "Sanıkların maktule maddi ve manevi acılar çektirerek, ă̆ırlı̆ğ ve süresi bakımından öldürme için gerekli olan ölçünün ötesinde eziyet etmesi, her an için ölüm sonucunu gerçekleştirebilme olanağ bulunan sanıkların maktule acı vermek için bu hareketleri tekrarlaması ve ölüm neticesini yavaş yavaş gerçekleştirmesi durumunun somut olayda olmamasına rağmen sanık ... hakkında TCK'nun 81. maddesi gereğince hüküm kurulması gerekirken yanılgılı değerlendirmeyle TCK'nun 82/1-b maddesi uygulanmak suretiyle fazla ceza tayin edilmesi;" Y. 1. CD. E. 2018/498 K. 2018/1213 T. 15.3.2018 (Karar metni için bkz. www.kazanci.com) (Erişim Tarihi: 10.12.2020)

115 Eser/Stenberg-Lieben, StGB $\S 211$ Rn. 27. 
kapsamda failin mağdura uzun bir süre silah doğrultması ancak tetiği çekmemesi halinde yerinde olarak "eziyet çektirerek" öldürmenin varlığının kabulünün gerektiği belirtilmektedir ${ }^{116}$. Bir diğer örnekse failin mağduru oldukça küçük ve keskin olmayan bir kesici aleti karnından saplayarak kalbine doğru bu işleme herhangi bir ara vermeksizin devam etmesinden verilebilir. Ancak verilen her iki örnekte de kesintisiz bir şekilde davranış gerçekleşmektedir ve "amaçta ve zamanda birlik" bulunduğundan davranışın tekrarından da bahsedilemeyecektir.

Ölüm neticesinin muhakkak eziyet niteliğindeki davranışlardan kaynaklanması zorunlu değildir ${ }^{117}$. Bu kapsamda örnek olarak failin mağdurun her bir parmağını tek tek kesmesi, sonra cinsel organını kesmesi, daha sonra ise silahla kafasından vurarak öldürmesi halinde ölüm neticesi eziyet çektirme kapsamındaki davranışlardan kaynaklanmamasına karşın bu nitelikli halin uygulanması verilebilir ${ }^{118}$. Mağdurun acıyı hissetmesi gereklidir ${ }^{119}$. Yani mağdurun ölümünden evvel eziyet çektirmeye ilişkin davranışların gerçekleştirilmesi gereklidir ${ }^{120}$. Şayet mağdur ilk darbenin etkisiyle ölmüşse, bundan sonra fail tarafından acı çektirmeye yönelik gerçekleştirilen davranışlar "eziyet çektirerek" öldürme kapsamında değerlendirilmez. Örneğin ilk davranışın ardından mağdurun ölmesi ancak bu esnadan sonra failin mağdurun öldüğ̈nü anlamadığı ve sonucun gerçekleşmesinden emin olmak amacıyla davranışlarına devam ettiğgi ${ }^{121}$ ya da mağdurun öldüğünü anlamasına karşın yakalanmamak amacıyla mağdurun vücudunu parçalara ayırdığı hallerde "eziyet çektirerek" öldürme söz konusu değildir ${ }^{122}$. Bu durumda

116 Tezcan/Erdem/Önok, s. 156, dp. 118.

117 Gözübüyük, s. 315-316; Erem, s. 56; Toroslu, Nevzat, s. 31.

118 Yaşar/Gökcan/Artuç, s. 2665.

119 Selçuk, "Canavarca", s. 472; Önder, s. 31.

120 Eser/Stenberg-Lieben, Rn. 27; Artuk/Gökcen/Yenidünya, s. 3012; Gökcen/Balcı, s. 157-158. "Ölüm olayının canavarca bir his ve işkence ve taziple husule getirilip getirtilmediğinin tespiti yönünden, kafanın boyundan bileklerin kollardan kesilmesinin şahıs canlı iken mi yoksa başka bir şekilde öldürüldükten sonra mı yapıldı̆̆ının Adli Tıp tarafindan" tespiti gereklidir. YCGK 1-18/80 T. 7.3.1988 (Karar metni için bkz. Önder, s. 31)

121 Bu durumda canavarca hissin varlığından da bahsedilemez. Bkz. Yaşar/Gökcan/Artuç, s. 2662. "Sanık Aydın'ın, tahrik altında yol üzerinde eşi olan maktulenin kafasına taşla vurup, bıçakla boğazını keserek öldürdüğ̈̈ olayda, canavarca his sevki ile öldürmenin şartlarının oluşmadığının gözetilmemesi” Y. 1. CD. E. 2011/1643 K. 2011/5407 T. 22.9.2011 (Karar metni için bkz. Gökcen/Balcı, s. 151, dp. 51)

122 Erman/Özek, s. 40; Tezcan/Erdem/Önok, s. 156-157; Önder, s. 31; Özbek, s. 227; Özbek/Doğan/Bacaksız, s. 126. "sanı̆̆ın maktul Ural'ı önce bıçaklayarak öldürdüğü, bıçak ve öldürücü yara sayısının öldürme suçunu meydana getirmeye yönelik olduğu, 
diğer nitelikli hallerin varllğg söz konusu değilse TCK'nın 81. maddesinden ve şartları varsa da TCK'nın 130. maddesinin 2. fikrası uyarınca "kişinin hatırasına hakaret" suçundan dolayı sorumluluğun varlığından bahsedilme$\operatorname{lidir}^{123}$.

İşkence suçunun işlenmesi neticesinde ölümün meydana gelmesi halindeyse neticesi sebebiyle ağırlaşmış işkence suçu vardır (TCK m. 95/4). Olayda neticesi sebebiyle ağırlaşmış işkence suçunun mu yoksa kasten öldürme suçunun "eziyet çektirerek" mi işlendiği konusundaki ayrımın failin kastının öldürmeye yönelik olup olmadığının tespitiyle gerçekleştirilmesi gereklidir ${ }^{124}$. Nitekim TCK'nın 95. maddesinin 4. fikrasının uygulama alanı bulduğu hallerde failde ölüm neticesine yönelik bir kast bulunmamaktadır ${ }^{125}$. Ayrıca işkence suçu, özgü suç olup failinin kamu görevlisi olması gereklidir. "Eziyet çektirerek" öldürme suçunun failinse herkes olması mümkündür ${ }^{126}$. Eziyet suçunun işlenmesi neticesinde mağdur ölmüşse ve failin kastı eziyet suçuna yönelikse artık neticesi sebebiyle ağırlaşmış yaralama suçundan ve bu kapsamda TCK'nın 87. maddesinin 4. fikrası uyarınca sorumluluk söz konusu olur ${ }^{127}$.

eziyet çektirerek öldürme suçunun unsuru sayılamayacağl, ölümden sonra cesedi parçalamaya çalışmasının işlediği öldürme suçunun kanıtlarını ortadan kaldırmaya yönelik olduğu gözardı edilerek hakkında 5237 Sayll TCK.nun 82/1-b maddesinin uygulanması" Y. 1. CD. E. 2011/3150 K. 2011/8175 T. 21.12.2011 (Karar metni için bkz. www.kazanci.com) (Erişim Tarihi: 16.12.2020)

Toroslu, Nevzat, s. 31; Erman/Özek, s. 40-41; Parlar, Ali: Türk Ceza Kanunu Şerhi, C. I, 2. Bas1, Bilge Yayınevi, Ankara 2015, s. 956.

124 Özbek/Doğan/Bacaksız, s. 128.

125 Dönmezer, s. 53; Gerçeker, Hasan: Yorumlu \& Uygulamalı Türk Ceza Kanunu, 4. Bası, Seçkin Yayıncılık, Ankara 2018, s. 889. Söz konusu durumda failde öldürmeye yönelik bir kast bulunmamasına karşın, failin en ağır ceza olan "ağırlaştırılmış müebbet hapis cezası"yla cezalandırılacağının hükümde öngörülmesinin, TCK'nın 3. maddesinin 1. fikrası uyarınca failin işlediği "fiilin ağırlığıyla orantılı ceza"ya tabi kılınmasına aykırılık oluşturduğu yönünde bkz. Tezcan/Erdem/Önok, s. 157.

126 Artuk/Gökcen/Yenidünya, s. 3013; Gökcen/Balcı, s. 158; Arslantürk, s. 395.

127 Ancak hem işkence hem de eziyet suçunda fail mağdurun ölebileceğini öngörmüş ve buna kayıtsız kalmışsa artık olası kastla öldürmenin varlığı kabul edilmelidir. Bkz. Sevük, Handan Yokuş: Türk Ceza Hukuku Özel Hükümler, 2. Bası, Adalet Yayınevi, Ankara 2019, s. 76. Ancak işkence ve eziyet öldürmek amacıyla yapılmadığından kasten öldürme suçunun basit halinin söz konusu olacağ 1 , örneğin işkence neticesinde ölüm meydana gelmişse TCK'nın 44. maddesi uyarınca sorumluluğun tespitinde TCK'nın 96. maddesinin 5. fikrasıyla olası kastla öldürmenin dikkate alınmak suretiyle belirlenmesi gerektiği belirtilmekteyse de (bkz. Koca/Üzülmez, s. 101-102) burada yalnızca olası kastla "eziyet çektirerek" öldürmenin varlığ kabul edilmelidir. 
TCK'nın 82. maddesinin (b) bendinde öngörülen iki nitelikli halin de iştirak halinde işlenmişse tüm ortaklar bakımından şartları varsa uygulama alanı bulacağı belirtilmelidirr ${ }^{128}$. Yine şahısta hata halinde de söz konusu nitelikli hallerin uygulanması söz konusudur ${ }^{129}$. Nitekim hükümde öngörülen nitelikli haller mağdurun sıfatından kaynaklanmamaktadır ${ }^{130}$. Sapma halindeyse amaç kişi bakımından TCK'nın 82. maddesinin (b) bendine teşebbüs, diğer kişi bakımındansa failin taksirle mi yoksa olası kastla $\mathrm{m} 1$ hareket ettiğine göre yapılan belirleme neticesinde gerçek içtima uyarınca sorumluluk belirlenmelidir ${ }^{131}$.

Yargıtay 1. CD. 2013/5375 sayılı kararında boşanmış iki kişinin tartışmas1 neticesinde eski eşlerden birinin diğerini yakarak öldürmesini ${ }^{132}$

128 Erman/Özek, s. 39; Tezcan/Erdem/Önok, s. 157. Ancak “canavarca his"sin kişiye özel psikolojik bir durumu ifade etmesi nedeniyle diğer ortaklar bakımından uygulama alanı bulamayacağı da savunulmaktadır. Bkz. Selçuk, "Canavarca", s. 470-471.

129 Demirbaş, Timur: Ceza Hukuku Genel Hükümler, 15. Bası, Seçkin Yayıncılık, Ankara 2020, s. 452.

130 Erman/Özek, s. 39.

131 Sapma halinde gerçek içtimanın değil, fikri içtimanın uygulanması gerektiği ve bu nedenle hangi suçun cezası ağırsa ondan dolayı cezalandırmanın yapılması gerektiği yönünde bkz. Tezcan/Erdem/Önok, s. 157.

132 "sanık Saniye ile maktülün 1976 yılında evlendikleri, beş tane müşterek çocukları olduğu fakat maktülün sanığa karşı şiddet uygulaması ve şiddetli geçimsizlik nedeniyle 2009 yılında boşandıkları ve boşanma kararı kesinleşmesine rağmen, nişanlanan ve evlenen çocukları nedeniyle aynı evde yaşadıkları, çocuklarının bazılarının boşanmadan haberdar olmadĭ̆l, maktülün boşanma sonrası da sanı̆̆a hakaret ederek şiddet uyguladı̆̆l, olay günü; maktülün başka bir kadın ile evlenmek amacıyla nüfus cüzdanını bulamaması ve sanığın sakladığını düşüncesi nedeniyle sanık ile tartıştığı, sanığı tehdit ederek, darp ettiği, aralarındaki kavganın evin dişında bahçede de devam ettiği sırada, orada bulunan pet şişedeki benzini maktülün başından aşă̆ıya döken sanığın, kibriti yakarak maktülü ateşe verdiği, maktülün ateşi söndürmek için sanığa sarıldı̆ğ, sanığın maktülü ittirerek uzaklaş̧tırdiğl, eve giderek yanan elini ve omzunu suya tuttuğu, bu sırada maktül kendini bahçede bulunan çeşmenin yalağına atarak ateşi söndürdüğü, ancak baş ve boyun bölgesinde ileri derecede yanıklar oluştuğu, yaralı halde yola çıkarak durdurduğu kamyon ile jandarma karakoluna gittiği, oradan hastaneye sevk edilen maktülün baş ve boyun bölgesindeki ağır yanık lezyonlarına bağlı gelişen larinks ödemi tablosu sonucu öldüğ̈̈ olayda; sanı̆̆ı maktülü ateşe vermesi ve yanması sırasında yaralı halde maktülü kendi haline bırakması ile ortaya çıkan kastının kullandiğ yöntem itibariyle canavarca hisle öldürme suçuna yönelik olduğu anlaşıldiğı halde TCK'nın 82/1-b, 29 ve 62 maddeleri uyarınca canavarca his ile adam öldürme suçundan hüküm kurulması yerine, TCK'nın 81. maddesi gereğince karar verilmesi," Y. 1. CD. E. 2013/2231 K. 2013/5375 T. 1.10.2013 (Karar metni için bkz. www.kazanci.com) (Erişim Tarihi: 10.12.2020) 
"canavarca hisle" öldürmek olarak kabul etmiştir ${ }^{133}$. Esasında burada Yargıtay'ın söz konusu kararı vermesinde failin sonraki davranışlarını dikkate aldığ1 görülmektedir. Nitekim mağdur, ateşi söndürmek için faile sarılmak istemiş ancak fail mağduru itmiş ve evine dönerek yanan elini ve omzunu söndürmüştür ${ }^{134}$. YCGK da 2019/146 sayılı kararında yakarak öldürmeyi canavarca hisle öldürme şeklinde değerlendirmiştir. YCGK, bu kararında evli olan failin, duygusal bir birlikteliği bulunduğu mağdurun Facebook hesabına girmesi ve mağdurun eski bir erkek arkadaşıyla yaptığ 1 yazışmaları fark etmesi üzerine, yakarak öldürme fiilini gerçekleştirmesiyle faili bu fiile iten neden karşılaştırıldığında ortada aşı1rı ölçüde bir orantısızlığın ve ölçüsüzlüğün bulunduğunu, failin bu fiilinin "toplumun ortak bilinci, duygusu ve vicdaninca hiçbir zaman onaylamayacak oluşu"nu gerekçe olarak göstermiştir. Ancak bu kararda YCGK, "maktulün üzerine benzin döküp tutuşturmak suretiyle vahşi bir yöntem” kullandığından bahsederek ${ }^{135}$ esa-

133 Yine Yargitay'ın benzer yönde verdiği bir diğer kararı şu şekildedir: “olay tarihinde mağdur Murat'ın eve gelmesi üzerine sanıklar Koray, Mustafa ve haklarındaki evrak tefrik edilen Yüksel ve Bora isimli şahısların daha önce evlerinden kaybolan eşyalardan dolayı sorumlu tuttukları mağduru sorguladıkları, bu nedenle aralarında tartışma çıktığı, sanık Mustafa ile Bora'nın mağduru kollarından tuttukları sırada sanık Koray ile yaşı küçük Bora'nın mağdurun elinden aldıkları tineri măgdurun boynundan ve kollarından aşağıya döktükleri, sanık Koray'ın elindeki çakmă̆ı ateşlemesi sonucu mağdurun üzerindeki giysilerin tutuştuğu, mă̆durun yanmakta olan montunu çıkartıp evin içine atarak dişarl kaçtığ ${ }_{l}$, metruk evin de bu esnada yandĭg l, mağdurun ikinci derece yaniğa maruz kalip hayati tehlike geçirmeyecek ve basit tıbbi müdahale ile giderilemeyecek nitelikte yaralandiğg olayda; sanıkların eylemlerinin TCK.nun 82/1-c maddesinde düzenlenen "yangın suretiyle adam öldürmeye teşebbüs suçu" niteliğinde olmadı $\breve{g}$, eylemlerinin TCK.nun 82/1-b maddesinde düzenlenen "canavarca bir his ile adam öldürmeye teşebbüs" suçunu oluşturduğu” Y. 1. CD. 2009/3634 E. 2011/1209 K. 2.3.2011 T. (Karar metni için bkz. Yaşar/Gökcan/Artuç, s. 2662). Ancak Yargıtay benzer nitelikte olan başka bir olayı ise eziyet çektirerek öldürme kapsamında değerlendirmiş olup, bu durum da birbiriyle çelişen kararlar verdiğinin göstergesi olarak kabul edilmelidir. Nitekim Yargıtay'ın söz konusu kararı şu şekildedir: "Kendisine terk eden katılan-mağdure Serpil'in işyerine silahla ve benzinlikten aldiğ pet şişe içerisindeki benzinle gelen saniğın katılan-mağdureye silahıyla ateş etmek için doğrultarak birkaç kez tetiğe basmasına rağmen silahın ateş almaması üzerine pet şişedeki benzini katılan-mağdurenin üzerine döktükten sonra çakmakla benzini yakarak katılan-mağdurenin yüz, boyun, gögüs, her iki üst ekstremite ön ve arka ile alt ekstremite önde 2.3 derecede yanıklara neden olarak hayati tehlike geçirecek şekilde yaralayarak öldürmeye teşebbüs ettiği olayda; saniğın eyleminde aynı zamanda eziyet çektirerek öldürmeye teşebbüs suçunun unsurlarının oluştuğu” Yargitay 1. CD. 2010/5763 E. 2011/4129 K. 28.6.2011 T. (Karar metni için bkz. Gökcen/Balcı, s. 149) Akyürek, s. 15.

135 YCGK E. 2017/1-905 K. 2019/146 T. 5.3.2019 (Karar metni için bkz. www.kazanci.com) (Erişim Tarihi: 12.12.2020) 
sında yine failin saikinden değil, suçu gerçekleştirme şeklinde hareket etmiştir. Bu kapsamda öğretide canavarca hissin, mahiyeti gereği mağdura karş1 vahşi bir öldürme yöntemi gerektirdiğini savunanlar da bulunmakta$\operatorname{dir}^{136}$. Nitekim bu görüşe göre eziyet çektirme, esasında canavarca hissin dışa vurumu olarak ortaya çıkmaktadır ve bu nedenle söz konusu iki ayrı nitelikli hal iç içedir. Canavarca hissin varlı̆̆ının tespitinin genelde failin dışa yansıyan davranışlarıyla tespit edilebileceği bunun da eziyet olarak ortaya çıktı̆̆ 1 belirtilmektedir ${ }^{137}$. Yine Yargitay 1. CD'nin 2013/5375 sayılı kararından farklı olarak YCGK bu kararında failin mağduru yakma fiilinin ardından gösterdiği pişmanlığı, yanan mağduru arabadaki paspasları da kullanarak mağdura sarılıp söndürmesini, hatta söndürürken kendisinin de ellerinin ve kollarının yanmasını, daha sonra failin mağduru hastaneye götürmesini dikkate almamışır. Ancak bu durumun dikkate alınmamasının gerekçesi olarak olayın gerçekleştiği yerin işlek bir yer olup üçüncü kişilerin de ellerindeki suyla mağduru söndürmek istemesi ve failin yakalanma korkusu nedeniyle söz konusu pişman olma hareketlerini gerçekleştirdiği belirtilmiştir. Yine de olayın gerçekleştiği yerin işlek olmasından hareketle failin pişmanlık duymayıp sırf yakalanmama korkusu nedeniyle bu şekilde hareket ettiğinin kabulü sorunludur.

Ayrıca YCGK burada yerinde olarak failin davranışı gerçekleştirdikten sonraki diğer davranışlarının saikini etkilemeyeceğini yani kendisini suç işlemeye iten hissini değiştirmeyeceğini belirtmiştir. Yargitay Cumhuriyet Başsavcıllığ ise failin davranışı gerçekleştirdiği ancak neticenin gerçekleşmesinden evvel yaptıklarının canavarca hissin yokluğunu belirttiğini ifade etmiştir. Bu nedenle "canavarca hisle" kasten öldürme suçu bakımından bu hissin, davranışın gerçekleştirilmesinden neticenin gerçekleşmesi anına kadar sürmesinin mi gerektiği yoksa yalnızca davranışın gerçekleştirildiği anda bulunmasının yeterli olup olmadığı tartışması ortaya çıkmaktadır. Bu durumda ise suçun işlendiği zamana ilişkin tartışmalar önem taşımakta ve suçun neticeli ve neticesiz suçlar bakımından ortak olan davranışın gerçekleştirildiği anda işlendiğinin kabulü gereklidir. Nitekim failin bir suçu işleme yönündeki iradesi, davranışı gerçekleştirdiği anda söz konusu olmaktadır ${ }^{138}$. Ancak yine de burada bizatihi yakma davranışı, fiilin işlenişs şekliyle ilgi-

136 Bayraktar, Köksal: "Kasten Adam Öldürme", Marmara Üniversitesi Hukuk Fakültesi Hukuk Araştırmaları Dergisi, Prof. Dr. Nur Centel'e Armağan, C. 19, S. 2, 2013, s. 72; Koca/Üzülmez, s. 99.

137 Özen, s. 136.

138 Hafızoğulları, Zeki/Özen, Muharrem: Türk Ceza Hukuku Genel Hükümler, 12. Bası, US-A Yayınc1lik, Ankara 2019, s. 37-38. 
lidir. Zira olayda canavarca hissin yani öldürme zevkinin varlığını gösteren başkaca bir delil bulunmamaktadır. Burada tartışılması gereken "eziyet çektirerek" öldürme olmalıdır. Nitekim mağdur olayda yanmanın etkisiyle hemen ölmemiş, hastaneye kaldırılmış ancak oldukça fazla acı çekmiş ve bu durumu da dile getirmiştir. Yakarak bir kimsenin öldürülmesi bizatihi süresi ve etkisi düşünüldügünde "eziyet çektirerek" öldürme kapsamında kabul edilebilir ${ }^{139}$. Ancak burada da her yakma fiiliyle öldürmede eziyet çektirerek öldürmeden bahsedilmemelidir. Nitekim failin mağdurla tartışması ve mağduru öldürmek istemesi ancak örneğin failin mağdura nazaran ufak tefek yapıya sahip olması, olayın gerçekleştiği yer itibariyle elinde ya da olayın gerçekleştiği yerde failin mağduru öldürmek için elindeki tek elverişli aracın yakarak öldürmeyi gerektirmesi halinde eziyet çektirerek öldürmenin varlığının kabulü sorunlu olacaktır.

Ceza mahkemelerince verilen her bir karar esasında normun yorumlanmasinı gerektirmekte ve yargı yorumundan bahsedilmesini gerektirmektedir. Yorum olmadan uygulama mümkün olmadığından, ceza mahkemelerince verilen her bir karar normun yorumudur. Yargitay ceza dairelerinin ve YCGK'nın kararları, bağlayıcı değildir, elbette ki gerekçesi ortaya konmak suretiyle ceza mahkemelerince aksi yönde kararların verilmesi mümkündür. Ancak YCGK kararları, genel ilkesel kararlardır ${ }^{140}$. Bu nedenle çelişkili kararların verilmemesinde fayda vardır.

Esasında hem uygulamada hem öğretide hem de gerekçede "canavarca hisle" kasten öldürme suçu bakımından verilen klasik örneği yakarak öldürme oluşturmaktadır ${ }^{141}$. Ancak yakarak öldürmenin varlığı bizatihi suçun "canavarca hisle" gerçekleştirildiği şeklinde yorumlanmamalıdır. Nitekim burada suçun gerçekleştiriliş şekli itibariyle canavarlığın söz konusu olduğu ve bunun da "eziyet çektirerek" öldürme şeklindeki nitelikli hale vücut vermesi az önce de belirtildiği üzere mümkündür ${ }^{142}$. Hatta Yargıtay'ın burada

\footnotetext{
139 Akyürek, s. 17-18.

140 Hafızoğulları/Özen, s. 104.

141 Akyürek, s. 9.
}

142 Ancak Yargıtay, ETCK döneminde dokuz yaşındaki bir çocuğun "hunharca öldürülmesi" bakımından 450. maddenin 3. fikrası kapsamında kasten öldürme suçunun "canavarca bir his sevki ile veya işkence ve tazip ile" gerçekleştirilmesiyle ilgili olarak herhangi bir değerlendirme yapmayıp bunun 29. maddenin son fikrası uyarınca temel cezanın artırılarak belirlenmesinde dikkate alınması gerektiğini belirtmiştir. Y. 1. CD. E. 2001/2743 K. 2001/3251 T. 18.9.2001 (Karar metni için bkz. www.kazanci.com) (Erişim Tarihi: 15.12.2020) 
ne "canavarca hisle" ne de "eziyet çektirerek" öldürmeyi kabul ettiği kararları da bulunmaktadır ${ }^{143}$.

Yakarak öldürme halinde ayrıca TCK'nın 82. maddesinin (c) bendinde kasten öldürme suçunun "yangın, su baskını, tahrip, batırma veya bombalama ya da nükleer, biyolojik veya kimyasal silah kullanmak suretiyle” işlenmesi şeklinde öngörülen nitelikli halin ${ }^{144}$ uygulama alanı bulması dahi mümkündür ${ }^{145}$. Burada örneğin yangında olduğu gibi kullanılan $\operatorname{aracın}^{146}$ ve suçun işleniş şeklinin ${ }^{147}$ bizatihi canavarca hissi kanıtlamak bakımından yeterli olmadığı yalnızca yardımcı olabileceği belirtilmelidir ${ }^{148}$.

Canavarca hissin varlığı halinde kasten öldürmenin ne şekilde gerçekleştiğinin herhangi bir önemi yoktur. Aksinin kabulü suçun canavarca hisle

“Maktul sanığın kapısına kocasının evde olmadiğ bir zamanı hesaplayarak gece gelmiş, öteden beri tekrarladiğı cinsi ilişkide bulunma isteğini bildirince onun ahlakdışı istek ve takibinden kurtulamayacağını anlayan sanık iffetini korumak için kocasının motosikletinde kullandiğ tenekedeki benzinden bir miktar doldurarak evin avlusu içinde odun koymaya ayrılmış ve evden bağımsız durumdaki odunlukta kendisini bekleyen maktulün yanına gidip benzini fevren üzerine serpmiş kibritle tutuşturmuştur. Sanığın eylem ve davranışları bu aşamada kalmıştır. Sanık odunluğun kapısını kapayarak maktulü yanarak ölüme terk etmemiştir. Yanmaya başlayan bu nedenle kaçan maktulü fiilen engellememiş etraftan yetişenlerin alevleri söndürmesine mani olmamış, alevler söndürülüp maktul hastahaneye kaldırılıp tedaviye alınmış, bir buçuk gün yaşadıktan sonra vefat etmiştir. Bu durumda sanığın işkence ve tazip kasdiyla hareket ettiği kabul edilemez." YCGK E. 1981/1-169 K. 1981/288 T. 6.7.1981 (Karar metni için bkz. www.kazanci.com) (Erişim Tarihi: 1.12.2020) Yine benzer yönde verilen bir diğer karar için bkz. YCGK 168/288, T. 29.6.1981 (Karar metni için bkz. Selçuk, "Canavarca", s. 479)

Söz konusu nitelikli halin TCK'nın 82. maddesinin (a) bendinde öngörülen "tasarlayarak" ya da (b) bendinde öngörülen "canavarca hisle" veya "eziyet çektirerek" öldürme kapsamında değerlendirilmesi mümkün olduğundan gerekli olmadığı yönünde bkz. Özbek/Doğan/Bacaksız, s. 129.

145 "canavarca hisle öldürme suçunun yasal unsurlarının da oluşmadı̆̆ı, sanığın maktule yumruk vurup bayılttıktan sonra arabanin bagajina koyup ardindan arabaya benzin dökerek ateşe vermek suretiyle maktulü öldürme eyleminin TCK'nun 82/1-c maddesinde düzenlenen yangın çıkarmak suretiyle öldürme suçunu oluşturduğu gözetilmeden yazılı şekilde TCK'nun 82/a-b maddeleri uyarınca hüküm kurulması, " YCGK E. 2012/1-1289 K. 2013/84 T. 19.2.2013 (Karar metni için bkz. www.kazanci.com) (Erişim Tarihi: 16.12.2020) Bir kimsenin yangın çıkarılarak öldürülmesi halinde hem "canavarca hisle" hem "eziyet çektirerek" hem de "yangın çıkarmak suretiyle" öldürmenin söz konusu olduğu, ancak fail hakkında tek bir nitelikli halin uygulanması gerektiği yönündeki farklı görüş için bkz. Özen, s. 140. 
işlenmesiyle eziyet çektirerek işlenmesinin birbirine karıştırılmasına sebebiyet verir ${ }^{149}$. Nitekim Yargıtay'ın suçun işleniş şeklini de dikkate alarak somut olayda canavarca hissin varlığını kabul ettiği kararları bulunmaktadır.

Failin herhangi bir acıma hissi bulunmaksızın bir kimseyi öldürmesi halinde artık canavarca hisle öldürmenin varlı̆̆ından bahsedilmesi gerektiğinden TCK'nın 82. maddesinin gerekçesinde bahsedilmiştir ${ }^{150}$. Ancak bizatihi acıma hissi olmaksızın öldürmenin "canavarca his" olarak değerlendirilmesi sorunludur. Nitekim faille mağdur arasında uzun süredir devam eden bir husumetin varllğg nedeniyle ya da failin mağdurun çocuğuna cinsel istismarda bulunmasının ardından failin mağduru herhangi bir acıma hissi bulunmaksızın öldürmesi halinde failin canavarca hisse sahip olduğu söylenemez $^{151}$. Ayrıca hükmün gerekçesinde canavarca histen bahsedebilmek için öldürmenin vahşi bir şekilde gerçekleştirilmesinin de gerektiğinden bahsedilmiştir $^{152}$. Bu kapsamda örnek olarak mağdurun yakılarak, uyurken kulağından kızgın yağ dökülerek ya da vücudunun parçalara ayrılarak öldürülmesi verilmiştir ${ }^{153}$. Bu nedenle her ne kadar "canavarca his", failin içinde bulunduğu psikolojik durumla ilgili olsa da gerekçedeki örnekler dikkate alındığında bunun fiilin gerçekleştiriliş şekliyle ilgili bir unsur olarak anlaşılması gerektiği de öğretide savunulmaktadır. Hatta bu gerekçeyle kasten öldürme suçunun nitelikli halleri bakımından yapılan sınıflandırmada "canavarca hisle" öldürmenin fiilin işleniş şekline göre yapılan ayrım içinde değerlendirildiği görülmektedir. Bu kapsamda kasten öldürmenin canavarca hissin etkisiyle "eziyet çektirerek" işlenmesinden bahsedilmektedir. ${ }^{154}$ Yine benzer şekilde canavarca hissin amaç ya da saik ile ilgili nedenler kapsamında değerlendirilmediği görülmektedir ${ }^{155}$. Bu kapsamda canavarca histen kasten öldürmenin acımasız, kötü ve zalim bir şekilde gerçekleştirilmesinin anlaşılması gerektiği ifade edilmektedir ${ }^{156}$. Buna karşın "canavarca hisle veya eziyet çektirerek" öldürme şeklindeki iki ayrı nitelikli halin de ETCK

\footnotetext{
149 Özbek/Doğan/Bacaksız, s. 126.

150 Şahin/Özgenç, s. 173.

151 Tezcan/Erdem/Önok, s. 155.

152 Acıma hissi bulunmaksızın bir kimsenin öldürülmesi halinde canavarca hissin söz konusu olduğu ve canavarca hisle birinin öldürülmesi halinde zaten bu fiilin vahşi bir yöntemle gerçekleştirilmiş olduğunun kabulünün gerektiği yönünde bkz. Centel/Zafer/ Çakmut, s. 47.

153 Gerekçe metni için bkz. Şahin/Özgenç, s. 173.

154 Soyaslan, s. 144.

155 Gökcen/Balcı, s. 129-133, 147.

156 Artuk/Gökcen/Yenidünya, s. 3008-3009.
} 
döneminde "ağırlatıcı sebep olarak faildeki sübjektif durum" başlığı altında incelendiği de görülmektedir ${ }^{157}$. Ancak gerekçede canavarca hissin varlığından bahsedilebilmesi için kasten öldürmenin aynı zamanda vahşi bir şekilde gerçekleştirilmesinin aranması sorunludur ${ }^{158}$. Nitekim fiilin vahşice gerçekleştirilmesi, fiilin işlenişine yönelik olup faili buna iten hisle ilgili değildir. Gerekçedeki bu ifade ve bu kapsamda verilen örnekler "canavarca hisle" öldürmeye değil, "eziyet çektirerek" öldürmeye uygun düşecek nitelikte$\operatorname{dir}^{159}$. Ancak burada gerekçenin yorum bakımından bir araç olup bağlayıcı olmadığ

Her ne kadar gerekçede mağdurun üzerinde kızgın yağın dökülmesinden bahsedilmişse de ETCK döneminde Yargıtay, kaynar yağın mağdurun üzerine dökülerek, ardındansa mağdurun boğularak öldürülmesini "canavarca hisle" değil "eziyet çektirerek" öldürme kapsamında değerlendirmiş$\operatorname{tir}^{160}$. TCK döneminde de Yargitay'ın söz konusu durumu "canavarca his" kapsamında değerlendirmediği görülmektedir ${ }^{161}$. Her ne kadar bu durumun gerekçeye uygun olmadığı ve gerekçeyle çeliştiği belirtilmekteyse ${ }^{162}$ de az

157 Önder, s. 22, 26.

158 Hatta gerekçede yer verilen yakarak öldürme şartları oluştuğu takdirde TCK'nın 82. maddesinin (c) bendinin; uyurken kulağa kızgın yă̆ dökülmesiyle TCK'nın 82. maddesinin (e) bendinin uygulanmasına sebebiyet verecektir. Ancak gerekçede kuramsal çerçevenin çizilmesi yerine örneklere yer verilmesi ve söz konusu örneklerin diğer bentlere de uygunluk göstermesi yerinde değildir. Bkz. Otacı, Öldürme, s. 489.

Yaşar/Gökcan/Artuç, s. 2661; Artuç, s. 185.

160 "maktülle ilişkiye girmek için kendi isteklerini yerine getirmesini söyleyerek, çay içmek teklifini yaptığını, maktülün elleri, ayaklarını bağladı̆̆ı, bundan sonra da çaydanlıkta kaynama noktasındaki zeytinyağını başından dökerek ikinci derecede yanıklar meydana getirdikten sonra, bağırmasına aldırmadan ayakları ile göğsüne basarak öldürdüğünü ikrar etmiş, otopsi zaptındaki tesbitler de bunu doğrulamıştır. İ̧̧kence ve tazip ile öldürme; öldürme eyleminden önce öldürülecek olana karşı işkence yapmayı hedef tutan, ölümü meydana getirmek bakımından zorunlu olmayan vahşice davranışlarda bulunmaktır. Olayımızda, sanığın ellerini ve ayaklarını bağladı̆̆ı maktülü boğarak öldürmesi dışında, kaynar zeytinyağını başından aşă̆ı dökmesi özel kastını göstermektedir.” Y. 1. CD. E. 1996/3925 K. 1997/547 T. 5.3.1997 (Karar metni için bkz. www.kazanci.com)

"Sanığın öldürme kastıyla eși olan mağdurun üzerine kızgın yă̆ dökmesinin canavarca hisle öldürmeye teşebbüs suçunun kanıtı sayılamayacağının gözetilmemesi” Y. 1. CD. E.2007/9461 K. 2009/2437 T. 29.4.2009 (Karar metni için bkz. Gökcen/Balcı, s. 149)

Artuk/Gökcen/Yenidünya, s. 3010, dp. 1005. Yine Yargıtay failin ölen abisinin öcünü almak amacıyla, abisinin taksirle ölümüne sebebiyet veren sanığın ailesine mensup mağdur çocuğun üzerine, çocuğu etkisiz hale getirebilmek amaciyla kaynar suyun dökülerek bayılmasının hemen ardından bıçakla boğazının kesilmesinde failin "canavarca hisle", "kan gütme saikiyle" ve de "eziyet çektirerek" öldürme suçunu işlediğine karar vermiştir. Söz konusu olayda kan gütme saikinin ve canavarca hissin varlığının kabul 
önce de ifade edildiği üzere gerekçenin bağlayıcı olmadığı bir kez daha belirtilmelidir.

TCK'nın 82. maddesinin (b) bendinde öngörülen "eziyet çektirerek" öldürmek bakımındansa gerekçede, kişinin anında değil, belli bir süreçte acı çektirilmek suretiyle öldürülmesinin anlaşılması gerektiği belirtilmiştir ${ }^{163}$. Örnek olaraksa, mağdurun gözlerinin çıkarılarak, kulağının ya da benzeri organlarının kesilerek acı çektirilmesi ${ }^{164}$ ve buna bağlı olarak da ölmesi verilmektedir ${ }^{165}$. Ancak mağdurun acı çekmesiyse zorunlu değildir. Örnek olarak mağdurun hissetme yeteneğinden yoksun olmas ${ }^{166}$, aldığ 1 eğitim ya da fiziksel yapısı nedeniyle dayanaklı olması, yine manevi bakımdan da her türlü eziyete katlanacak dinginliğe sahip olması halinde yine de söz konusu nitelikli hal uygulanır. Zira bu nitelikli hal, davranışın gerçekleştiriliş şekliyle ilgili olup failin objektif olarak eziyet kavramı kapsamında değerlendirilen davranışlarda bulunması yeterlidir ${ }^{167}$.

edilmesi sorunludur. Nitekim hem öç alma hem de zevk için öldürmenin aynı olayda bağdaşması mümkün değildir. Ayrıca olayda "eziyet çektirerek" öldürmenin kabulü de bir diğer sorunu oluşturmaktadır. Nitekim boğazın bıçakla kesilmesi mağdur tarafından hissedilmemiştir. Bkz. Y. 1. CD.'nin 22/03/2011 tarihli ve 760/1714 sayılı kararı ve eleştirisi için bkz. Otacı, "Canavarca", s. 1489-1497. Ancak öğretide "kan gütme saikiyle", canavarca hissin aynı olayda bağdaşmasının mümkün olduğu da belirtilmektedir. Bu görüşe göre "eziyet çektirerek" öldürmenin temelinde canavarca hissin varlığ 1 yatmaktadır ve ikisinin yan yana tek bir neden olarak kabul edilmesi gerekmektedir. Bkz. Soyaslan, s. 144.

163 "Sanık Recep’in, önceden tanıdı̆̆ maktulü babasının çalıştırmış olduğu gazinoya götürdüğ̈̈, gazinoda bulunan küçük kulübenin içine soktuğu, burada maktulün ellerini ve ayaklarını bağladĭ̆ı, ruhsatsız tabancasının kabzasıyla başına vurduğu, ağzını bez parçasıyla kapattığı, falakaya yatırdiğg, defalarca darp ettiği, diğer sanıklar Ali Osman, Ümit, Ferdi ve Aziz'in de kulübeye girip maktule vurduklarl, son olarak Recep'in güneş şemsiyesinin demir sapı ile vurarak maktulü öldürdügü̈... olaydan üç gün sonra bulunan ceset üzerinde yapllan adli tıp incelemesinde, ölümün zorlamalı ölüm olduğunun anlaşıldığı olayda" Yargıtay "eziyet çektirerek öldürme" suçunun varlığını kabul etmiştir. Yargitay 1. CD. E. 2008/868 K. 2009/8046 T. 23.12.2009 (Karar metni için bkz. Gökcen/Balcı, s. 154, dp. 58)

"Savunmasındaki sıralama doğrultusunda, sanı̆̆ın, maktülü önce kurşunladı̆̆ı, bilahare henüz hayatta iken penisini kestiği, ardından da çevreden temin ettiği demir telle yine muhitten edindiği ă̆ır taşı maktüle bağlayarak onu bu bedeni acı ortamında suya attığ gözetilerek "işkence ve tazip" özel amactyla hareket ettiğinin kabulü sonucu TYC.nın 450/3, 51/2, 59.maddelerince cezalandırllması gerekirken yazılı şekilde 448, 51/2, 59.maddelerince hüküm tesisi" Y. 1. CD. E. 2001/2007 K. 2001/3444 T. 1.10.2001 (Karar metni için bkz. www.kazanci.com) (Erişim Tarihi: 16.12.2020)

166 Eser/Stenberg-Lieben, "StGB § 211 Mord”, Rn. 27.

167 Erman/Özek, s. 41. 
Canavarca hissin varlığın konusundaki şüphe halinde söz konusu nitelikli halin uygulanmasından bahsedilemez ${ }^{168}$. Aynı durum "eziyet çektirerek" öldürme bakımından da geçerlidir. Bu nedenle örneğin şayet eziyet oluşturan davranışların gerçekleştirildiği esnada mağdurun hayatta olduğu tespit edilemiyorsa artık "şüpheden sanık yaralanır" ilkesi gereğince nitelikli halin uygulanmasından bahsedilemez ${ }^{169}$. Ayrıca hem "canavarca hisle" hem de "eziyet çektirerek" öldürme TCK'nın 82. maddesinin (b) bendinde ağırlaştırıcı neden olarak öngörülmüş olup, ceza sorumluluğunu artıran bir nedendir. TCK'nın 2. maddesinin 3. fikrası uyarınca "suç ve ceza içeren hükümler" bakımından geniş yorum mümkün değildir. Bireylerin temel hak ve özgürlüklerine en ağır müdahaleyi içeren ve de ceza sorumluluğuna yol açan hükümlerin dar yorumlanması gereklidir.

\section{KASTEN YARALAMA SUÇUNUN "CANAVARCA HISLE" IŞLENMESI}

TCK'nın 82. maddesinin (b) bendinin uygulanmasıly ilgili olarak “canavarca his"ten anlaşılması gerekenin ne olduğu hususunda tereddütler bulunmaktayken, 7242 say1l "Ceza ve Güvenlik Tedbirlerinin İnfazı Hakkında Kanun ile Bazı Kanunlarda Değişiklik Yapılmasına Dair Kanun"un 31100 sayılı Resmi Gazete'de yayınlanarak 15.4.2020 tarihinde yürürlüğge

"sanığın canavarca hisle ya da eziyet çektirerek öldürme amaclyla hareket ettiğini kabule yeterli her türlü kuşkudan uzak yeterli kesin kanıt bulunmadiğı anlaşıldiğı halde, sanığın TCK'nun 81. maddesi gereğince cezalandırllması yerine suç vasfinda yanılgıya düşülerek yazılı şekilde TCK'nun 82/1-b maddesi gereğince hüküm kurularak fazla ceza tayini," Y. 1. CD. E. 2016/748 K. 2017/1103 T. 5.4.2017; “Sanığın önce biyık kesme makası ile maktulenin yüzüne ve kafasına doğru hızlı bir şekilde ve arka arkaya çok sayıda vurduğu, makasın kırılması üzerine, bu kez cebindeki bıçağı çıkartarak, ağzını, yӥzünü, gözünü, boynunu, kafasını ve vücudunu bıçaklamaya devam ettiği, maktulenin vücudunda 35'i toplu bölgede, ancak küçüklü büyüklü toplam 94 yerde kesici delici alet yaralanmasının tespit edildiği ve iç organ ve boyun büyük damar yaralanmasına bağlı olarak öldüğ̈ iddia ve kabul edilmesine göre; Canavarca hisle öldürme, sırf öldürmüş olmak için öldürme, ölenin acı çekmesinden zevk duymak için öldürme olup, eziyet çektirerek öldürme ise ölümü meydana getirme bakımindan zorunlu olmayan ve ölüme takaddüm eder vahşice hareketler olup sanığın öldürme kastının yanında işkence ya da eziyet çektirme kastının da bulunması gerektiği, somut olayda ise ölüm neticesini almak için mağdura çok sayıda bıyık kesme makası ve bıçak darbesi vuran sanığın, canavarca hisle ya da eziyet çektirerek öldürme amactyla hareket ettiğini, kabule yeterli her türlü kuşkudan uzak yeterli kesin kanit bulunmadiğı gözetilmeksizin kasten öldürme suçundan cezalandırılmasına karar verilmesi yerine, suç vasfinda hata yapılması sonucu yazılı şekilde hüküm kurulması" Y. 1. CD. E. 2016/1273 K. 2017/3353 T. 18.10.2017 (Karar metinleri için bkz. www.kazanci.com) (Erişim Tarihi: 5.12.2020) 
girmesiyle birlikte söz konusu Kanun'un 11. maddesiyle TCK'nın 86. maddesinin 3. fikrasına (f) bendi eklenerek, kasten yaralama suçunun "canavarca hisle" işlenmesi, kasten yaralama suçunun nitelikli hali olarak öngörülmüştür. Ayrıca bu değişiklikle TCK'nın 86. maddesinin 3. fikrasının (a) ila (e) bentlerinden farklı olarak suçun "canavarca hisle" işlenmesi halinde hükmün 1. veya 2. fikrasına göre belirlenecek temel cezanın "yarı oranında" değil "bir kat" arttırılacağı belirtilmiştir. Hükmün gerekçesine bakıldığında işlenen suçla etkin bir şekilde mücadele edebilmek ve caydırıcıllğı sağlayabilmek adına söz konusu nitelikli halin öngörüldüğü ifade edilmiştir. Ayrıca gerekçede bu nitelikli hal bakımından örnek olarak mağdurun yüzüne kezzap atılması verilmiştir ${ }^{170}$.

7242 sayılı Kanunla gerçekleştirilen söz konusu değişikliğin yapılmasında basına da yansıyan ve kamuoyunu da etkileyen Berfin Özek olayı etkili olmuştur ${ }^{171}$. Bu kapsamda panik mevzuat örneği olarak ortaya çıkmakta$\operatorname{dir}^{172}$. Nitekim bu olayda Berfin Özek'in yüzüne eski erkek arkadaşı tarafından kezzap atılmış ve bu durum Berfin Özek'in bir gözünün kaybına ve yüzünün büyük bir bölümünün yanmasına neden olmuştur. Söz konusu nitelikli halin ihdasına gerçekten gerek olup olmadığg da başka bir sorunu oluşturmaktadır. Nitekim böyle bir durumda zaten TCK'nın 61. maddesi uyarınca temel cezanın belirlenmesi bakımından alt sınırdan uzaklaşılmak

170 Söz konusu bendin yine TCK'nın 86. maddesinin 3. fikrasındaki diğer bentlerle birlikte işlenmesi halindeyse (f) bendinden ötürü sadece temel cezada bir kat artırımın yapılacağı şu şekilde belirtilmiştir: "fikrada yer alan diğer bentlerin yeni eklenen (f) bendiyle birlikte uygulandı̆̆ durumlarda da sadece bir kat artırım yapılacaktır. Örneğin, silahtan sayllan kezzabın yüze atılmast suretiyle kasten yaralama suçunun işlenmesi halinde 86 ncı maddenin üçüncü fikrasinın hem (e) bendinin hem de Teklifle eklenen (f) bendinin birlikte uygulanması söz konusu olacaktır. Bu durumda, temel ceza, daha fazla artırım öngören (f) bendi uyarınca sadece bir kat artırllacaktır. Silah sebebiyle (e) bendi uyarınca ayrıca yarı oranında artırım yapılmayacaktır." Gerekçe metni için bkz. Adalet ve Kalkınma Partisi Grup Başkanvekili Denizli Milletvekili Cahit Özkan, Milliyetçi Hareket Partisi Grup Başkanvekili Sakarya Milletvekili Muhammed Levent Bülbül ve Afyonkarahisar Milletvekili Ali Özkaya ile 57 Milletvekilinin Ceza ve Güvenlik Tedbirlerinin İnfazı Hakkında Kanun ile Bazı Kanunlarda Değişiklik Yapılmasına Dair Kanun Teklifi (2/2762) ve Adalet Komisyonu Raporu, Türkiye Büyük Millet Meclisi, Yasama Dönemi 27, Yasama Y1l1 3, s. 16.

171 "İnfaz düzenlemesinde Berfin Özek sürprizi... Muhalefet partileriyle paylaşılan taslak teklife göre, kasten yaralama suçunun "canavarca hisle" işlenmesi durumunda faillere verilecek cezanın üst sınırı artırılıyor. Bu kişilere 18 yıla kadar hapis cezası verilmesi öngörülüyor" (Söz konusu haber metni için bkz. https://www.haberturk.com/sondakika-haberler-infaz-teklifinde-berfin-surprizi-cezanin-ust-siniri-18-yila-cikariliyor2623256) (Erişim Tarihi: 17.12.2020) 
suretiyle hükmün tesisi mümkündür. Aksinin kabulü kamuoyunu rahatsız eden her bir özel durumun nitelikli hal olarak kanuna yansımasına ve bunun sonunun gelmemesine sebebiyet verecektir ${ }^{173}$. Ayrica her ne kadar söz konusu değişiklik yapılmışsa da zaten TCK'nın 7. maddesinin 2. fikrası uyarınca Berfin Özek'in yüzüne kezzap atan fail hakkında bu aleyhe değişikliğin uygulanması mümkün değildir.

Öğretide gerçekleştirilen bu değişikliğin yerine TCK'nın 86. maddesinin 1. fikrasında cezanın üst sınırı olarak altı yılın öngörülmesi önerilmektedir. Bu görüşe göre, "kezzap" zaten TCK'nın 6. maddesi uyarınca silah sayılacağından cezanın yarı oranında arttırılarak dokuz yıla, sabit iz olması nedeniyleyse bir kat arttırılmak suretiyle failin zaten on sekiz yıla kadar cezalandırılabileceği belirtilmektedir ${ }^{174}$.

7242 sayılı Kanun'un gerekçesinde de “canavarca his”ten anlaşı1ması gerekene ilişkin verilen örneğin sorunlu olduğu belirtilmelidir. Nitekim verilen örnek failin hissinden ziyade suçun işlenişinde kullanılan araçlara ${ }^{175}$ ve suçun işleniş şekline ilişkindir. Bu nedenle daha doğru ifadeyle "canavarca his" ifadesi yerine "eziyet çektirerek" işlenmesinin aranması daha yerinde olabilirdi.

\section{KASTEN ÖLDÜRME VE YARALAMA SUÇUNUN "CANAVARCA HISLE" İŞENMESİ HALINDDE ÖZELLIK ARZ EDEN BAZI HUSUSLAR}

Öğretide haksız tahrikle canavarca hissin bir arada bulunup bulunamayacağ 1 hususunun tartışmalı olduğu görülmektedir. Bu kapsamda görüşlerden ilkine göre, haksız tahrikin uygulanmasını gerektiren koşulların varlığ durumunda, örneğin mağdurun kasten öldürülmesi halinde, "canavarca his" şeklindeki nitelikli hal uygulama alanı bulamaz ${ }^{176}$. Bu görüş, canavarca hissin nedensiz yere öldürme ya da yaralama olarak tanımının yapılması halinde makul gözükmektedir. Nitekim Yargıtay'ın da bu yönde kararları

173 Alan Akcan, Esra: "7242 Sayılı Ceza ve Güvenlik Tedbirlerinin Infazı Hakkında Kanun ile Bazı Kanunlarda Değişiklik Yapılmasına Dair Kanunun Genel Değerlendirilmesi”, Koronavirüs Döneminde Güncel Hukuki Meseleler Sempozyumu: Bildiri Tam Metin Kitab1 29 - 30 May1s 2020, s. 644.

174 Özbek/Doğan/Bacaksız, s. 217.

175 Özbek/Doğan/Bacaksız, s. 217.

176 Özbek, s. 226; Parlar, s. 956. Nitekim bu görüşe göre "canavarca his" esasında saiktir. Nasıl ki kan gütme ya da töre saikiyle işlenen kasten öldürme suçlarıyla haksız tahrik bağdaşmıyorsa burada da bağdaşmamalıdır. Ancak yargı kararlarında söz konusu durumun açıkça ortaya konmaması eleştirilmektedir. Bkz. Otacı, Öldürme, s. 132-133, 490. 
mevcuttur ${ }^{177}$. Ancak engel bir durumun olmadığı, ikisinin aynı anda bulunabileceği de öğretide savunulmaktadı1 ${ }^{178}$. Yargitay'ın yeni uygulamalarına bakıldığındaysa bu şekilde karar verdiği görülmektedir ${ }^{179}$.

177 "Sanığın, ölenden kaynaklanan haksız hareketin verdiği kızgınlık sonucu, aniden meydana gelen, eşini bıçaklayarak, sonra boğazını keserek öldürdüğü olayda, suçun canavarca his ile veya eziyet çektirerek işlenmesi halinin varlı̆̆ını gösteren kesin ve yeterli kanıt bulunmadiğ " Yargitay 6. CD. 3008/336, 24.4.2008 T. (Karar metni için bkz. Tezcan/Erdem/Önok, s. 154, dp. 105); "Pek çok öldürücü vasıfta yara ika edilmesinin, başlı başına suçun canavarca his sevkiyle işlendiğini kabule yeterli bulunmadığ gibi haksız tahrik altında suç işlenmesinde de canavarca his sevkinden söz edilemeyeceği, öldürdükten sonra sirf cesetten ve cezadan kurtulmak amactyla cesedi parçalama girişimlerinin de suçun vasfinı değiştirecek mahiyette bir vakıa olmadiğı cihetle, yara çokluğu ve suç kasitlarındaki yoğunluk teşdid sebebi yapılarak sanıkların adam öldürme suçundan TCK.'nun 64/l. maddesi delaletiyle 448, 51/1, 55/3 ve 59. maddeleri ile tecziyeleri gerekirken yazılı şekilde suç vasfinın belirlenmesinde yanılgıya düşülmesi” Y. 1. CD. E. 2003/1911 K. 2003/2232 T. 7.10.2003; “küçük yaştaki saniğın olay gecesi zorla ırzına geçen maktülü bu olayın doğurduğu şiddetle gazap ve üzüntünün etkisiyle penisini kesip, ardı ardına yaptığ bıçak darbeleriyle öldürdüğ̈̈nün açıklıkla anlaşılması karşısında, TCK.nun 448, 51/2, 55/3, 59. maddelerin uygulanması suretiyle cezalandırılmasına karar verilmesinde zorunluluk bulunduğu halde yazıll şekilde hüküm kurulması" Y. 1. CD. E. 1994/2431 K. 1994/2977 T. 27.9.1994 (Karar metinleri için bkz. www.kazanci.com) (Erişim Tarihi: 1.12.2020) Yargıtay'ın bu son kararında failin haksız tahrik altında kasten öldürme suçunu işlemesi nedeniyle canavarca histen bahsedilememektedir. Ancak, burada "eziyet çektirerek" öldürmenin varlığından bahsetmek mümkündür. Bkz. Tezcan/Erdem/Önok, s. 154, dp. 105. Nitekim kasten öldürme suçunun gerçekleşmesi bakımından gerekenin ötesinde bir davranışın gerçekleştiği görülmektedir.

178 Selçuk, "Canavarca”, s. 478; Soyaslan, Doğan, Ceza Hukuku Özel Hükümler, 12. Bas1, Yetkin Yayınları, Ankara 2018, s.144; Gökcen/Balcı, s. 152; Özen, s. 137.

"birahanede çallşan ve para karşıllĭ̆ erkeklerle ilişkiye giren maktule ile bir süre birlikte yaşayan, ancak daha sonra onun birahanede çalışmasına ve başkalartyla birlikte olmasına rıza göstermeyen evli ve iki çocuk sahibi sanığın, olay günü saat 02.00 siralarında evine gittiği maktulenin kapıyı açmaması üzerine ona küfrederek aşağıya inip bir süre beklediği ve daha sonra maktulenin onu içeri alması üzerine aralarında çıkan tartışma sonrası onu canavarca hisle öldürdügü olayda; Maktulenin yaşam tarzının sanık yönünden tahrik oluşturmayacağl, olay öncesinde veya sirasında maktuleden kaynaklanan sanık lehine tahrik oluşturacak herhangi bir haksı söz veya eylem bulunmadı̆̆ gibi olaydan önce sanığın maktuleye küfretmesiyle ilk haksız hareketin kendisinden kaynaklandiğı anlaşıldiğı halde, oluşa ve dosya kapsamına uygun olmayacak gerekçeyle ve sanığın daha az ceza almaya yönelik soyut nitelikteki savunmasına itibarla tahrik hükmü uygulanarak eksik ceza tayini," Y. 1. CD. E. 2009/6525 K. 2010/3023 T. 27.4.2010 (Karar metni için bkz. www.kazanci.com) (Erişim Tarihi: 5.12.2020) Dikkat edileceği üzere Yargıtay burada canavarca hissin varlığını kabul etmiş ancak haksız tahrikle canavarca hissin aynı olayda birbirleriyle bağdaşmayacağ gerekçesiyle değil, haksız tahrikin koşulları oluşmadığından cezada indirim yapılmasını 
Canavarca hisle haksız tahrikin bir arada bulunup bulunamayacağ canavarca histen anlaşılması gerekene göre değişecektir. Örneğin daha evvel de bahsedildiği üzere faili suça iten nedenle, öldürme ya da yaralama fiili arasında açık bir orantısızlığın bulunduğu haller canavarca his olarak kabul edilirse haksız tahrikle canavarca hissin bir arada bulunabileceğinin kabulü gerekir. Örneğin kasten öldürme suçu bakımından, (A)'nın (B)'ye 'gerizekalı" diyerek hakaret etmesi, (B)'ninse bunun üzerine (A)'y1 öldürmesi halinde esasında (B)'nin, (A)'yı öldürmek bakımından sahip olduğu nedenle, ölüm neticesi arasında orantısızlık vardır. Ancak canavarca histen yerinde olarak kasten öldürme suçu bakımından Al. CK'nın 211. paragrafının 2. fikrasında geçen "öldürme zevki" yani failin sırf öldürmek için, öldürme zevkiyle, can sıkıntısı nedeniyle ya da sırf heyecan yaşamak üzere birini öldürmesi; yine kasten yaralama suçuyla ilgili olarak da "yaralama zevki" yani failin sırf yaralamak için, yaralama zevkiyle, can sıkıntısı nedeniyle ya da heyecan yaşamak üzere birini yaralaması anlaşılacak olursa haksız tahrikle canavarca hissin bağdaşmayacağının kabulü gereklidir.

Kısmi akıl hastalığıyla canavarca hissin bir arada bulunmasıysa mümkündür ${ }^{180}$. Canavarca hisle örneğin kasten öldürme suçunu işleyen failin ahlaki kötülüğünün aşırı derecede olması, otomatikman onun akıl hastalığına sahip olduğu anlamına gelmez. Ancak mehaz kanunda canavarca histen evvel "yalnızca" ifadesine yer verildiğinden kısmi akıl hastalığıyla canavarca hissin yan yana gelmeyeceği zira burada artık kasten öldürmenin "yalnızca canavarca histen" kaynaklanmadı ̆̆ kabul edilmektedir ${ }^{181}$.

Esasında canavarca hisle bir kimsenin öldürülmesi ya da yaralanmas1 halinde, akla ilk olarak failin böyle bir saikle hareket etmesi halinde akıl hastası olup olmadığ heyecan yaşamak üzere örneğin birinin öldürülmesinde, failin otomatikman patolojik olduğu söylenemez. Bu kapsamda TCK'nın 32. maddesi uyarınca ak1l hastalığının bulunup bulunmadı $\breve{g}$, bulunuyorsa da bunun kısmi mi yoksa tam mı olduğunun araştırılması gereklidir ${ }^{182}$. Buna karşın öğretide aksi de savunulmaktadır. Bu görüşe göre, kısmi akıl hastalığının canavarca hisse

bozma nedeni yapmıştır. Ancak olayda canavarca hissin bulunmadığını belirtmekte fayda vardir.

180 Şensoy, Naci: "Cezai Mes'uliyeti Tamamen veya Klsmen Kaldıran Akli Maluliyet", İstanbul Üniversitesi Hukuk Fakültesi Mecmuas1, C. 16, S. 1-2, Ocak 1950, s. 149-150;

Gökcen/Balcı, s. 153.

182 Schneider, StGB $\S 211$, Rn. 52; Eschelbach, Ralf: BeckOK StGB, 48. Ed., München 2020, StGB § 21, Rn. 16. 
neden olması mümkün olup, kısmi akıl hastalığının doğurduğu canavarca his nedeniyle ceza artırılırken, kısmi akıl hastalığının doğurduğu his nedeniyle cezanın azaltılması çelişkidir ${ }^{183}$. Ayrıca çoğu akıl hastalığının temelinde canavarca his gibi hislerin olduğu, bu nedenle de bu iki durumun bir arada bulanamayacağ belirtilmektedir $^{184}$. Ancak söz konusu görüş kabul edildiği takdirde isnat yeteneğini azaltan nedenlerin doğurduğu his nedeniyle hiçbir şekilde suçun nitelikli hallerinin uygulama alanı bulmasından bahsedilemez. Ayrıca mevzuatta açıkça buna ilişkin bir engel olmadığından kısmi akı1 hastalığıyla canavarca hissin bir arada uygulanması mümkündür.

Ayrıca "canavarca hissin" tam sarhoşluk halinde söz konusu olamamasına karşın kısmi sarhoşluk halinde söz konusu olabileceği, zira tam sarhoşluk halinde failin aklının alkol nedeniyle tamamen durduğu, failin davranışlarının iradi ve bilinçli olmadığı, kısmi sarhoşluktaysa failin davranışlarının iradi ve bilinçli olmadığından bahsedilemeyeceği belirtilmektedir. Yine yaş küçüklüğüyle de bu nitelikli halin bağdaşmayacağı ifade edilmektedir ${ }^{185}$. Ancak sarhoşluk bakımından burada sarhoşluğun iradi olup olmadığında göre TCK'nın 34. maddesi uyarınca değerlendirme yapılması gerektiğinden örneğin iradi olarak alkol alınmışsa, tam ya da kısmi sarhoşluk şeklinde bir ayrıma gidilmeksizin şartları varsa failin ceza sorumluluğunun kabulü gerekmektedir. Yine yaş küçüklüğü bakımından da bağdaşmama durumundan bahsedilemez. Zira yaşı küçük olan bir kimsenin de bir suçu işlemesi ve bu kapsamda fail olması mümkün olup, kanun koyucunun tercihine göre (TCK m. 31) yaşı küçük olanın cezalandırılmaması ya da cezasında indirim yapılmas1 mümkündür.

\section{SONUÇ}

Kasten öldürme suçu bakımından TCK'nın 82. maddesinin (b) bendinde ve de kasten yaralama suçu bakımından 86. maddesinin 3. fikrasının (f) bendinde yer verilen "canavarca his" ifadesi sorunludur. Zira bu ifade muğlaktır. Elbette ki bu ifadeden bahsedildiğinde ister istemez her bir bireyin aklında belli bir çağrışım oluşmaktaysa da oluşan bu çağrışımın herkes bakımından ortak olduğunu söylemek iddialı olur. Esasında, özü itibariyle bir kimsenin öldürülmesinin dahi canavarlık olarak kabul edilmesi mümkündür. Bu kapsamda “canavarca his”ten neyin anlaşılması gerektiğinin belli

\footnotetext{
183 Önder, s. 27; Toroslu, Nevzat, s. 31.

184 Bayındır, Sinan: Türk Ceza Hukukunda Akıl Hastalığı, 1. Bası, On İki Levha Yayınc1lik, İstanbul 2018, s. 66.

185 Selçuk, "Canavarca", s. 470.
} 
olmadığı ve bunun sorunlara yol açtığı ifade edilmelidir. Nitekim bu kavramdan "yırtıcı bir hayvan" anlaşılıyor ve bu kapsamda mecaz yapılıyor olsa dahi söz konusu durum "eziyet çektirerek" öldürmeyi de akla getirmektedir. Yine bu ifadeden mecaz olarak "yırtıcı bir hayvan"ın anlaşılması da bizatihi sorunludur. Nitekim söz konusu durumda, yırtıcı hayvan hayatta kalabilmek ve karnını doyurabilmek adına başka bir canlıyı öldürmektedir.

Bu ifade yerine fiilin "yalnızca yabanıl (hayvanca) kötü yüreklilik itkisi (içtepisi) ile" işlenmesi şeklindeki ifadenin kullanılması önerilmekteyse de gerek kasten öldürme gerekse de kasten yaralama suçunun işlenmesinde "kötü yürekliliğin" bulunmadığını söylemek güçtür. Nitekim her iki suç da insan hayatını ve vücut dokunulmazlığını üstün tutan günümüz anlayışında "normal" bir davranış olarak kabul edilemez.

Yargıtay'ın canavarca hissi yorumladığı kararlara bakıldığındaysa çelişkilere rastlanmaktadır. Yine öğretide de üzerinde uzlaşının sağlandığı bir tanıma gidilemediği görülmektedir. Bu durumun temelinde kasten öldürme suçuyla ilgili olarak hem "canavarca hisle" hem de "eziyet çektirerek" öldürmeye aynı bent altında yer verilmesi yatmaktadır. "Eziyet çektirerek" öldürmede, öldürmenin işleniş şekli itibariyle canavarca gerçekleştirildiğini söylemek mümkündür ki belki de bu durum dahi söz konusu iki nitelikli halin birbirine karıştırılmasına sebebiyet vermektedir. Örneğin hem Yargitayca hem de öğretice yapılan "sırf öldürmek için öldürmek" şeklindeki tanım dahi sorunludur. Nitekim her bir ölüm neticesini kasteden davranış mahiyeti itibariyle "öldürmek için öldürmeyi" de kapsamına almaktadır. Yine "nedensiz yere öldürme"nin anlaşılması da sorunludur. Bu kapsamda silahını denemek için öldürmek örneği verilmekteyse de burada da silahın denenmesi gibi bir neden bulunmaktadır. Yine "sırf öldürmek için öldürmek" de esasında öldürmenin nedenidir.

Canavarca histen, faili öldürmeye iten saikin normal şekilde izahının güç olmasının anlaşılması gerektiği de öğretide savunulmaktadır. Ancak burada da söz konusu tanım sorunludur. Bir kimsenin diğer bir kimseyi öldürmesi hukuka uygunluk nedenlerinden örneğin meşru savunmanın bulunması halinde izahı mümkündür ki söz konusu durumda zaten suç yoktur. Yine bir kimsenin diğerine küfretmesi nedeniyle öldürülmesi halinde haksız tahrikin koşullarının varlığına karşın sırf küfrettiği için birinin öldürülmesinin normal bir şekilde izahı güçtür. Esasında her bir öldürme fiili bak1mından nedeni ne olursa olsun söz konusu yorumun yapılması mümkündür.

Kasten öldürme suçunun söz konusu nitelikli halinden anlaşılması gereken bu kadar tartışmalıyken, bir de aynı nitelikli halin kasten yaralama 
suçu bakımından öngörülmesi bir diğer sorunu oluşturmaktadır. "Canavarca his" kavramından anlaşılması gerekenin ne olduğu belli değilken, bir de bunun için kasten öldürme suçuyla ilgili olarak mevzuatta yer verilen ve en ağır ceza olan "ağırlaştırılmış müebbet hapis cezası"nın verilmesi; yine kasten yaralama suçu bakımından da cezada ağırlaştırılmaya gidilmesi problemlidir.

Çalışmada da değinildiği üzere "canavarca his" bakımından uygulamada birbirine benzeyen olaylarla ilgili olarak farklı kararların verildiği görülmektedir. Nitekim Yargıtay'ın kararlarına bakıldığında failin gerçekleştirdiği fiilden hareketle canavarca hissin varlığının bulunup bulunmadığını araştırmak gibi bir yanılgıya düştüğü görülmektedir. Elbette ki TCK'nın 82 . maddesinin (b) bendinde öngörülen iki ağırlaştırıcı nedenin bir olayda aynı anda bulunması mümkündür. Ancak fiilin eziyet çektirerek gerçekleştiriliyor olmas1, failin otomatikman canavarca hisle hareket ettiği şeklinde bir ön kabule sebebiyet vermemelidir. Söz konusu ön kabulün temelinde TCK'nın 82. maddesinin (b) bendine ilişkin gerekçe de yatmaktadır. Hatta öğretide de gerekçedeki yorumun esas alınarak söz konusu bentten canavarca hissin etkisiyle işlenen "eziyet çektirerek" öldürmeden bahsedenlerin bulunduğu ve bu nitelikli halin bir bütün olarak değerlendirilerek suçun işleniş şekli kapsamında değerlendirilmesi gerektiğini savunanlar bulunmaktadır. İki ayrı nitelikli hale aynı bentte yer verilmesinin bir diğer nedeni olarak yine iki ayrı nitelikli hale ETCK'nın 450. maddesinin (3). bendinde birlikte yer verilmesinin de etkili olduğu belirtilmelidir. Ancak kasten öldürme suçuyla ilgili olarak örneğin bu suçun "tasarlayarak" işlenmesi nasıl ki TCK'nın 82. maddesinin (a) bendinde bağımsız ve tek başına ayrı bir nitelikli hal olarak öngörülmüssse benzer düzenlemenin (b) bendinde öngörülen söz konusu nitelikli haller için de gerçekleştirilmesinde fayda vardır.

Kasten yaralama suçuna ilişkin olarak 7242 sayılı Kanun'un gerekçesinde "canavarca his"ten anlaşılması gerekene ilişkin verilen örneğin de sorunlu olduğu belirtilmelidir. Kasten öldürme suçunun nitelikli halini oluşturan "canavarca his"ten anlaşılması gerekenin belirlenmesi konusunda sorunlar varken, bir de bu belirsizliğin kasten yaralama suçuna işlenmesi yerinde değildir. Nitekim verilen örnek failin hissinden ziyade suçun işleniş şekline ilişkindir. Bu nedenle daha doğru ifadeyle "canavarca his" ifadesi yerine "eziyet çektirerek" ifadesinin kullanılması daha yerinde olabilirdi.

"Canavarca his" şeklinde ifade edilen nitelikli halin yürürlükten kaldırılmasında ve bunun yerine farklı bir ifadenin kullanılmasında fayda vardır. Bu kapsamda kasten öldürme suçu bakımından Al. CK'nın 211. paragrafının 2. fikrasında kullanılan "öldürme zevkiyle"; kasten yaralama suçu bakımın- 
dansa söz konusu nitelikli halin varlığ konusunda 1srarcı olunacaksa "yaralama zevkiyle" ifadesinin kullanılması önerilebilir. Bu kapsamda failde başkalarının yaşamını ve vücut dokunulmazlığını aşağı görme ve hiçe sayma şeklindeki duygunun varlığı aranmalıdır. Ayrıca failin bu fiilleri gerçekleştirmesi bakımından mağdurun faile herhangi bir neden vermemiş olması gerekmektedir. Ceren Özdemir cinayetinde olduğu üzere tesadüf eseri failin önüne çıkan bir kimseyi öldürmeye ilişkin saf kötülüğü, tümüyle keyfiyet gereği ya da öldürmeden haz alması, adeta amiyane tabiriyle "spor olarak mağdur avına çıkması" bu kapsamda değerlendirilmelidir. Yine kasten yaralama suçuyla ilgili olarak da failin sırf yaralamak için, yaralama zevkiyle, can sıkıntısı nedeniyle ya da heyecan yaşamak üzere birini yaralaması bu kapsamda kabul edilmelidir. Nitekim fail için hedef alınan mağdurun herhangi bir neden olmaksızın başka bir kimseyle değiştirilmesi mümkündür. Bir diğer çözüm önerisiyse "canavarca his" ifadesinin kullanılmasında ssrarc1 olunmak isteniyorsa bunun TCK'nın 6. maddesinde tanımlanmas1 olabilir. Nitekim "canavarca his", hem kasten öldürme suçu hem de kasten yaralama suçu bakımından ağırlaştırıcı neden olarak öngörülmüş olup, ceza sorumluluğunu artıran bir nedendir. Böylece olayda "canavarca hissin" bulunup bulunmadığı hususunun netliğe kavuşması mümkün hale gelecek ve uygulamada birbiriyle çelişen kararların verilmesine de engel olunabilecektir. 


\section{KAYNAKÇA}

Adalet ve Kalkınma Partisi Grup Başkanvekili Denizli Milletvekili Cahit Özkan, Milliyetçi Hareket Partisi Grup Başkanvekili Sakarya Milletvekili Muhammed Levent Bülbül ve Afyonkarahisar Milletvekili Ali Özkaya ile 57 Milletvekilinin Ceza ve Güvenlik Tedbirlerinin İnfazı Hakkında Kanun ile Bazı Kanunlarda Değişiklik Yapılmasına Dair Kanun Teklifi (2/2762) ve Adalet Komisyonu Raporu, Türkiye Büyük Millet Meclisi, Yasama Dönemi 27, Yasama Y11 3.

Akyürek, Güçlü: "YCGK Kararı Işı̆̆ında Canavarca Hisle veya Eziyet Çektirerek Kasten Öldürme Suçu (TCK m. 82/1-b)", Bahçeşehir Üniversitesi Hukuk Fakültesi Dergisi, C. 15, S. 185-186, Ocak-Şubat 2020, s. 9-19.

Alan Akcan, Esra: "7242 Sayılı Ceza ve Güvenlik Tedbirlerinin Infazı Hakkında Kanun ile Bazı Kanunlarda Değişiklik Yapılmasına Dair Kanunun Genel Değerlendirilmesi”, Koronavirüs Döneminde Güncel Hukuki Meseleler Sempozyumu : Bildiri Tam Metin Kitabı 29 - 30 May1s 2020, s. 635-687.

Arslantürk, Mustafa: Öldürme Suçları Açıklamalı - Örnekli - Notlu İçtihatlı - Gerekçeli, 2. Bası., Adalet Yayınevi, Ankara 2020.

Artuç, Mustafa: Kişilere Karşı Suçlar, 2. Bası, Adalet Yayınevi, Ankara 2018.

Artuk, Mehmet Emin/Gökcen, Ahmet/Yenidünya, A. Caner: Türk Ceza Kanunu Şerhi, C. 2, 2. Bs, Adalet Yayınevi, Ankara 2014.

Bayındır, Sinan: Türk Ceza Hukukunda Akıl Hastalığı, 1. Bası, On İki Levha Yayınc1lık, İstanbul 2018.

Bayraktar, Köksal: "Kasten Adam Öldürme", Marmara Üniversitesi Hukuk Fakültesi Hukuk Araştırmaları Dergisi, Prof. Dr. Nur Centel'e Armağan, C. 19, S. 2, 2013, s. 57-77.

Centel, Nur/Zafer, Hamide/Çakmut, Özlem: Kişilere Karşı İşlenen Suçlar, C. I, 3. Bası, Beta Basım Yayım Dağıtım A.Ş., İstanbul 2016.

Demirbaş, Timur: Ceza Hukuku Genel Hükümler, 15. Bası, Seçkin Yayınc1lik, Ankara 2020.

Devellioğlu, Ferit: Osmanlıca - Türkçe Ansiklopedik Lugat, 31. Bası, Aydın Kitabevi, Ankara 2015. 
Dönmezer, Sulhi: Kişilere ve Mala Karşı Cürümler, 16. Bası, Beta Basım Yayım Dağıtım A.Ş., İstanbul 2001.

Erem, Faruk: "Adam Öldürme", Ankara Üniversitesi Hukuk Fakültesi Dergisi, C. 10, S. 1, 1953, s. 33-91.

Erman, Sahir/Özek, Çetin: Ceza Hukuku Özel Bölüm Kişilere Karşı İşlenen Suçlar, Dünya Yayıncılık A.Ş., İstanbul 1994.

Eschelbach, Ralf: BeckOK StGB, 48. Ed., München 2020.

Eser, Albin/Stenberg-Lieben, Detlev: Schönke/Schröder Strafgesetzbuch Kommentar, 30. Aufl, Verlag C.H. Beck oHG, München 2019.

Gerçeker, Hasan: Yorumlu \& Uygulamalı Türk Ceza Kanunu, 4. Bası, Seçkin Yayıncılık, Ankara 2018.

Gökcen, Ahmet/Balcı, Murat: Kasten Öldürme Kasten Yaralama Organ ve Doku Ticareti Suçları, 2. Bası, Adalet Yayınevi, Ankara 2015.

Gözübüyük, Abdullah Pulat: Alman, Fransız, İsviçre ve İtalyan Ceza Kanunlariyle Mukayeseli Türk Ceza Kanunu Açıklaması, C. IV, Sevinç Matbaası, Ankara (Tarihsiz).

Hafizoğulları, Zeki/Ketizmen, Muammer: "5237 sayılı Türk Ceza Kanunu'nda Hayata Karşı Suçlar', Y. 66, S. 1, 2008, s. 143-154.

Hafızoğulları, Zeki/Özen, Muharrem: Türk Ceza Hukuku Genel Hükümler, 12. Bas1, US-A Yayıncıl1k, Ankara 2019. (Genel)

Hafızoğulları, Zeki/Özen, Muharrem: Türk Ceza Hukuku Özel Hükümler Kişilere Karşı Suçlar, 6. Bası, US-A Yayıncılık, Ankara 2017. (Özel)

Koca, Mahmut/Üzülmez, İlhan: Türk Ceza Hukuku Özel Hükümler, 6. Bası, Adalet Yayınevi, Ankara 2019.

Kühl, Kristian: Lackner/Kühl Strafgesetzbuch Kommentar, 29. Aufl., Verlag C.H. Beck oHG, München 2018.

Majno Ceza Kanunu Şerhi, C. 3, Yargıtay Yayınları No: 8, Ankara 1980.

Neumann, Ulfrid/Saliger, Frank: Nomoskommentar Kindhäuser/Neumann/ Paeffgen, Strafgesetzbuch, 5. Aufl., Nomos.

Olgun, Eser: “Kasten Öldürme Suçunun Türk-Alman Karşılaştırmalı Ceza Hukuku Bakımından Incelenmesi", Marmara Üniversitesi Hukuk Fakültesi Hukuk Araştırmaları Dergisi, Prof. Dr. Nur Centel'e Armağan, C. 19, S. 2, 2013, s. 1631-1666.

Otacı, Cengiz: "Karar Incelemesi Kan Gütme Saikiyle ve Canavarca Hisle Kasten Öldürme Suçu", İstanbul Üniversitesi Hukuk Fakültesi Mecmuas1, C. LXXI, S. 1, 2013, s. 1489-1498. (“Canavarca”) 
Otacı, Cengiz: Genel Hükümlerle Bağlantılı Olarak Kasten İnsan Öldürme Suçları, 1. Bası, Seçkin Yayıncılık, Ankara 2009. (Öldürme)

Önder, Ayhan: Şahıslara ve Mala Karşı Cürümler ve Bilişim Alanında Suçlar, Filiz Kitabevi, İstanbul 1994.

Özbek, Veli Özer: TCK İzmir Şerhi Yeni Türk Ceza Kanununun Anlamı, C. II, Seçkin Yayıncılık, Ankara 2008.

Özbek, Veli Özer/Doğan, Koray/Bacaksız, Pınar: Türk Ceza Hukuku Özel Hükümler, 15. Bası, Seçkin Yayıncılık, Ankara 2020.

Özen, Mustafa: Ceza Hukuku Özel Hükümler, 3. Bası, Adalet Yayınevi, Ankara 2019.

Öztürk, Bahri/Erdem, Mustafa Ruhan: Uygulamalı Ceza Hukuku ve Güvenlik Tedbirleri Hukuku, 20. Bası, Seçkin Yayıncılık, Ankara 2020.

Parlar, Ali: Türk Ceza Kanunu Şerhi, C. I, 2. Bası, Bilge Yayınevi, Ankara 2015.

Savaş, Vural/Mollamahmutoğlu, Sadık: Türk Ceza Kanununun Yorumu, C. 3, 1. Bası, Seçkin Yayınevi, Ankara 1995.

Schneider, Hartmut: Münchener Kommentar zum StGB, Bd. 4, 3. Aufl., Verlag C. H. Beck, München 2017.

Selçuk, Sami: “Ana Dili Bilinci, Türkçe ve Hukuk Dilimiz", Dokuz Eylül Üniversitesi Hukuk Fakültesi Dergisi, Prof. Dr. Durmuş Tezcan'a Armağan, C. 21, Özel Say1, 2019, s. 3013-3023. ("Hukuk")

Selçuk, Sami: "Karşılaştırmalı Hukuk Açısından Canavarca His Sevkiyle Adam Öldürme”, Yargitay Dergisi, C.14, S. 4, Ekim 1988, s. 467-482. ("Canavarca")

Sevük, Handan Yokuş: Türk Ceza Hukuku Özel Hükümler, 2. Bası, Adalet Yayınevi, Ankara 2019.

Soyaslan, Doğan: Ceza Hukuku Özel Hükümler, 12. Bası, Yetkin Yayınları, Ankara 2018.

Şahin, Cumhur/Özgenç, İzzet: Türk Ceza Hukuku Gazi Külliyatı, 1. Bası, Seçkin Yayıncılık, Ankara 2005.

Şensoy, Naci: "Cezai Mes'uliyeti Tamamen veya Klsmen Kaldıran Akli Maluliyet", İstanbul Üniversitesi Hukuk Fakültesi Mecmuası, C. 16, S. 1-2, Ocak 1950, s. 110-156.

Tezcan, Durmuş/Erdem, Mustafa Ruhan/Önok, Murat: Teorik ve Pratik Ceza Özel Hukuku, 17. Bası, Seçkin Yayıncılık, Ankara 2019. 
Toroslu, Haluk: "Temel Cezanin Belirlenmesinde Amaç ve Saik", Uğur Alacakaptan'a Armağan, C. I, 1. Bas1, İstanbul Bilgi Üniversitesi Yayınları, İstanbul 2008, s. 697-703.

Toroslu, Nevzat: Ceza Hukuku Özel Kısım, 10. Bası, Savaş Yayınevi, Ankara 2019.

Türk Dil Kurumu, Türkçe Sözlük, 11. Bas1, Türk Dil Kurumu Yayınları, Ankara 2011.

Yaşar, Osman/Gökcan, Hasan Tahsin/Artuç, Mustafa: Yorumlu Uygulamalı Türk Ceza Kanunu, C. 2, 2. Bası, Adalet Yayınevi, Ankara 2014.

Yılmaz, Ejder: Hukuk Sözlüğü, 9. Bası, Yetkin Yayınları, Ankara 2005. 